\title{
17. A DIATOM RECORD SPANNING 114,000 YEARS FROM SITE 893, SANTA BARBARA BASIN ${ }^{1}$
}

\author{
Eileen Hemphill-Haley² and Elisabeth Fourtanier ${ }^{3}$
}

\begin{abstract}
Drilling at Site 893 provided the first opportunity to examine a pre-Holocene record of diatom biostratigraphy and paleoclimatology from Santa Barbara Basin. The diatoms studied were taken at approximately 500- to 1000-yr intervals in the core, spanning the past $114,000 \mathrm{yr}$ in Hole $893 \mathrm{~A}$, and provide evidence for past changes in climate and diatom productivity in the Southern California Bight. Diatom preservation ranges from excellent in finely laminated sediment to poor in bioturbated deposits that were more thoroughly exposed to silica-undersaturated intermediate waters. Dominant taxa in modern Santa Barbara Basin, Chaetoceros spp. and Thalassionema nitzschioides, are likewise dominant in the Quaternary record at Site 893. The Pleistocene/Holocene transition is identified by the appearance of several subtropical species, particularly Fragilariopsis doliola, which persist throughout the Holocene. This pattern is consistent with observations off northern California and Oregon, suggesting that the introduction of $F$. doliola is a reliable chronostratigraphic marker along much of the length of the California Current. Diatom flux was high during part of Oxygen Isotope Stage 3 (30-46 ka), as determined from diatom mass accumulation rates, but it was greatly diminished preceding the transition to Oxygen Isotope Stage 2 (24-26 ka). During the glacial maximum at $20 \mathrm{ka}$, diatom flux remained several orders of magnitude lower than during Stage 3. High numbers of benthic diatoms do not correlate with low eustatic sea level, including the glacial maximum. Instead, gradual decreases in relative abundances of benthic diatoms from Oxygen Isotope Stage $5 \mathrm{~d}$ to Stage $2(\sim 105-15 \mathrm{ka})$ could be attributed to preservation differences between younger and older deposits, or to a long-term trend in decreasing downslope transport through time. Allochthonous freshwater diatoms are rare throughout the Hole 893A record, but several small increases during Oxygen Isotope Stages $4(\sim 65 \mathrm{ka})$ and $5(\sim 85 \mathrm{ka})$ may record increased wind transport of continental diatoms during cold intervals.

A new diatom variety, Thalassiosira simonsenii var. minor. Hemphill-Haley var. nov., and a new combination, Paralia sol (Kützing) Hemphill-Haley comb. nov., are proposed.
\end{abstract}

\section{INTRODUCTION}

Hole $893 \mathrm{~A}$ was drilled at a water depth of $538 \mathrm{~m}$ at $34^{\circ} 17.0^{\prime} \mathrm{N}$, $120^{\circ} 02.2^{\prime} \mathrm{W}$ in the Santa Barbara Basin, about $20 \mathrm{~km}$ off the coast of Southern California (Fig. 1; Kennett et al., 1994). The $196.5 \mathrm{~m}$ of hemipelagic sediment at this site represents the first recovery of preHolocene deposits in Santa Barbara Basin. In this paper we describe first a diatom record for Santa Barbara Basin that spans the interval from the early part of the last interglacial period to the present. Second, we demonstrate changes in diatom assemblages relative to fluctuations in climate, upwelling, and productivity in the California Current and concentrations of dissolved oxygen in Santa Barbara Basin at Site 893 .

Diatom production overlying Santa Barbara Basin occurs throughout the year, but is particularly vigorous during the spring, summer, and early fall when the North Pacific atmospheric highpressure cell generates strong equatorward winds and upwelling in the California Current (Reimers et al., 1990). Nutrient-rich water, which is upwelled to the surface near Point Conception, flows southward, generating high production in surface waters overlying the basin (Hickey, 1993). The combination of high surface-water productivity with oxygen-poor intermediate water, which enters the basin over a sill in the oxygen-minimum zone at $475 \mathrm{~m}$, results in generally restricted levels of dissolved oxygen on the basin floor, including episodes of suboxia when burrowing faunas are excluded and

'Kennett, J.P., Baldauf, J.G., and Lyle, M. (Eds.), 1995, Proc. ODP, Sci. Results, Vol. 146 (Pt. 2): College Station, TX (Ocean Drilling Program).

${ }^{2}$ U.S. Geological Survey, 345 Middlefield Rd., MS-999, Menlo Park, CA 94025, U.S.A.

3Diatom Collection, Department of Invertebrate Zoology and Geology, California Academy of Sciences, Golden Gate Park, San Francisco, CA 941 18-9961, U.S.A. annual couplets of light-dark laminae, or varves, are preserved (Soutar and Crill, 1977; Reimers et al., 1990; Schimmelmann et al., 1990). Increasing levels of dissolved $\mathrm{O}_{2}$ allow the incursion of burrowing faunas, and sedimentary structures indicate this by changes from disrupted laminations to homogenous, thoroughly bioturbated sediment. Diatom preservation is best in undisturbed laminated sediment, and decreases with increasing bioturbation of the sediment. The combination of high diatom productivity with enhanced biogenic preservation during episodes of bottom-water suboxia make Santa Barbara Basin an excellent site for studying fluctuations in the diatom record that may reflect climatically driven changes in the California Current, particularly in laminated and intermittently laminated intervals.

\section{METHODS}

Regularly spaced samples were collected from near the 100-101$\mathrm{cm}$ interval in each section, with additional samples collected at irregular intervals to demonstrate differences between adjacent laminated and bioturbated sedimentary sections. Diatom analyses for the remainder of Hole 893A ( 114-160 ka) are in progress (J. Baldauf, pers. comm., 1994). Age control for our analyses (Figs. 2-6) is based on the benthic foraminiferal isotope curve of Kennett (this volume).

Samples were processed with $30 \% \mathrm{H}_{2} \mathrm{O}_{2}$ to remove organic material, and rinsed several times with distilled water. An aliquot of the cleaned sample was allowed to dry on a cover slip, which was then fixed to a glass slide with Hyrax. When possible, 300 valves (excluding Chaetoceros spp.) were counted on random traverses across the slide at a magnification of $1250 \times$ (Table 1, backpocket). Species identified as freshwater or brackish/marine benthic members of various genera were combined under the "benthic" and "freshwater" categories (Fig. 4; Table 1, backpocket). Diatom fragments were counted using the technique described by Laws (1983). 


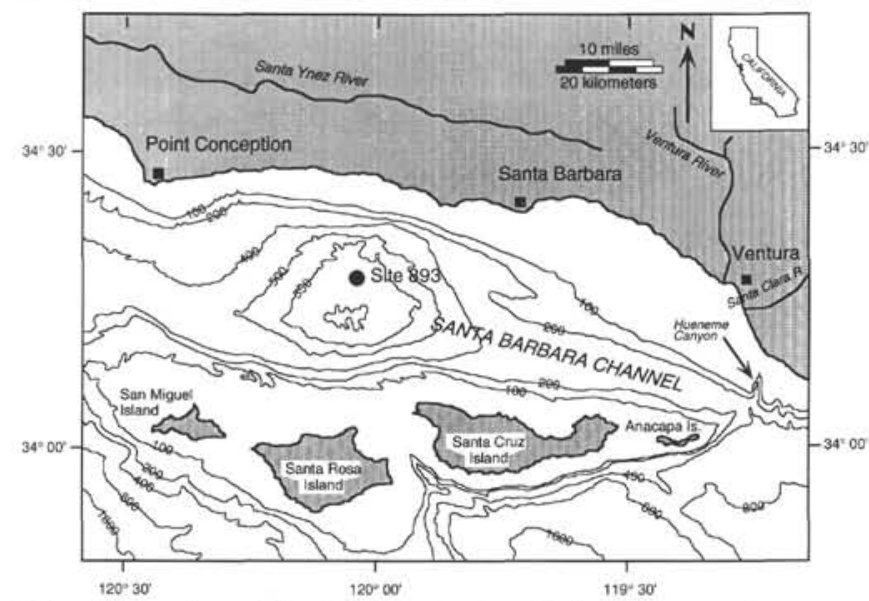

Figure 1. Location of Site 893, Santa Barbara Basin (bathymetry in meters).

Chaetoceros spp. resting spores were counted separately from other diatoms in order to contrast the relative occurrences of the two groups and emphasize occurrences of diatom taxa that are less abundant than the prolific Chaetoceros group. The delicate vegetative cells of Chaetoceros are rarely found in marine sediment, and we did not attempt to distinguish possible rare occurrences of vegetative cells from the overwhelmingly dominant numbers of resting spores. The ratio of Chaetoceros spp. spores to all other diatoms (Table 1, backpocket) is based on the first 200 specimens observed on random traverses across the slide.

In order to compare diatom concentrations in adjacent laminatedand bioturbated-sediment intervals of Oxygen Isotope Stage (OIS) 3 age, and at the transition from OIS-3 to OIS-2, quantitative analyses were completed on 27 samples from Cores $146-893 \mathrm{~A}-4 \mathrm{H}$ to $8 \mathrm{H}$ (Table 2). Quantitative analyses were not completed for the remaining samples because of time constraints. The sample-processing technique is as follows: approximately $1-2 \mathrm{~cm}^{3}$ of sediment is freeze dried, weighed, and cleaned with $10 \mathrm{~mL} 30 \% \mathrm{H}_{2} \mathrm{O}_{2}$ and $10-\mathrm{mL} 1 \mathrm{M}$ $\mathrm{HCl}$ in $30-\mathrm{mL}$ distilled $\mathrm{H}_{2} \mathrm{O}$. The sample is then neutralized by repeated rinses with distilled $\mathrm{H}_{2} \mathrm{O}$. After centrifuging to decant excess water, approximately a 5-mg split of the cleaned sample is transferred to a $1000-\mathrm{mL}$ settling chamber filled with distilled $\mathrm{H}_{2} \mathrm{O}$ and allowed to settle onto cover slips attached to a metal stand on the bottom of the chamber. The excess cleaned sample is weighed, freeze-dried, and reweighed to determine the percent difference between the wet and dry sample. After $24 \mathrm{hr}, \mathrm{H}_{2} \mathrm{O}$ is siphoned from the settling chamber to a level approximately $1-2 \mathrm{~cm}$ above the cover-slip stand, and the rest is evaporated with a heat lamp. When dry, the cover slips are mounted on glass slides with Hyrax. Number of diatom valves per gram of clean dry sediment (valves/g) was estimated by counting the number of specimens in several traverses across the cover slip; in each case $>1000$ specimens were counted. The fraction of the sample examined is determined by the area traversed on the cover slip relative to the total settling area for the sample in the $500-\mathrm{mL}$ beaker, using the relationship

\# valves/g = [(\# valves counted/sample split weight $)]$ $\times[($ (height of the cover slip) $\times$ (width of the field of view) $\times$ (number of vertical traverses)) / (total area of settling chamber)].

The valves/g data were transformed to diatom mass accumulation rates (MARs, in valves $\mathrm{cm}^{-2} \mathrm{k} . \mathrm{y} .^{-1}$ ) using the bulk MARs of Gardner and Dartnell (this volume).

Light microscope photomicrographs were made with an Olympus BH-2 microscope and automatic camera system with Ilford PANF 50 film, using Normarski interference contrast. Scanning electron micrographs were made using a Cambridge 250 Mark II SEM at the U.S. Geological Survey in Menlo Park, California.

\section{DIATOMS}

Diatom productivity in Santa Barbara Basin is ultimately tied to the influx of upwelled, nutrient-rich surface waters which flow from the north during the spring to early fall, and the incursion of warmer surface waters from the south when upwelling relaxes during the late fall and winter (Hickey, 1993). The seasonal succession of diatoms in Santa Barbara Basin (Reimers et al., 1990) consists of an early spring bloom dominated by Skeletonema costatum, followed by a bloom of Chaetoceros spp. usually in April and May. Pseudonitzschia spp., Leptocylindrus danicus and Detonula pumila, which are dominant during the summer, give way to the production and deposition of very large frustules of Coscinodiscus, particularly C. granii, C. centralis, and $C$. wailesii during the fall. Thalassionema nitzschioides is dominant during the winter (C. Lange, pers. comm., 1994).

Although this seasonal succession is recognizable by scanning electron microscope in varved sediment a few hundred years old (Lange and Schimmelmann, 1994), differential preservation and dissolution of diatom valves within a few meters below the seafloor creates major differences between fossil and modern assemblages. The dominant early-spring taxon, $S$. costatum, only occurs consistently in the upper few meters of Hole 893A, and in isolated samples of OIS3 age (Fig. 2). No evidence of Pseudonitzschia was observed in any fossil samples, and except for a few occurrences, large valves ( $>150$ $\mu \mathrm{m}$ diameter) of the dominant fall taxa, Coscinodiscus spp., were typically observed as fragments.

The two dominant diatom taxa at Hole 893A are Chaetoceros spp. and Thalassionema nitzschioides (Fig. 2). Reimers et al. (1990) reported that both Thalassionema and Chaetoceros occurred throughout the year in Santa Barbara Basin, but relative abundances of $T$. nitzschioides (and $T$. bacillaris) were an order of magnitude greater during the late fall and winter, whereas abundances of Chaetoceros were several times greater during the spring upwelling as compared with the rest of the year. Although vegetative cells of the late-spring upwelling group Chaetoceros spp. are similar to Skeletonema in their fragility, some members of the genus produce dissolution-resistant resting spores that persist in fossil deposits. Occurrences of resting spores underestimate the actual flux of Chaetoceros spp. because many more vegetative cells than resting spores are produced (Rines and Hargraves, 1986; Sancetta and Calvert, 1988), and the taphonomy of some thickly silicified spore walls is probably not comparable to the vegetative valves of any other species. However, occurrences in Hole 893A of Chaetoceros spp. resting spores and Thalassionema spp. represent a record similar to present-day productivity in Santa Barbara Basin.

\section{Diatom Preservation}

Reliable biostratigraphic and paleoecological reconstructions are dependent on a variety of post-depositional taphonomic processes that tend to alter fossil diatom assemblages. In Santa Barbara Basin, the best-preserved diatom assemblages are found in nonbioturbated, laminated deposits, whereas diatom preservation is generally poor in deposits that have been more thoroughly exposed to silica-undersaturated bottom waters through disruption by burrowing faunas. This kind of preservational bias has similarly been observed in numerous cores from the continental slope off California south of $35^{\circ} \mathrm{N}$, in which diatom preservation in Quaternary sediment is generally poor with the exception of undisturbed laminated deposits (Hemphill-Haley, 1994).

Differences in diatom mass accumulation rates (MARs, in valves/ $\mathrm{cm}^{2}$ k.y.) between adjacent laminated and bioturbated intervals between about 26-47 ka were calculated in order to quantitatively examine differences in preservation between the two lithologies (Fig. 3). Diatom MARs are determined by multiplying a sedimentation rate by the number of diatom valves per gram, and for our calculations a constant sedimentation rate was used for adjacent bioturbated and laminated intervals. Applying a constant to both lithologies re- 


\section{Oxygen-isotope stage}

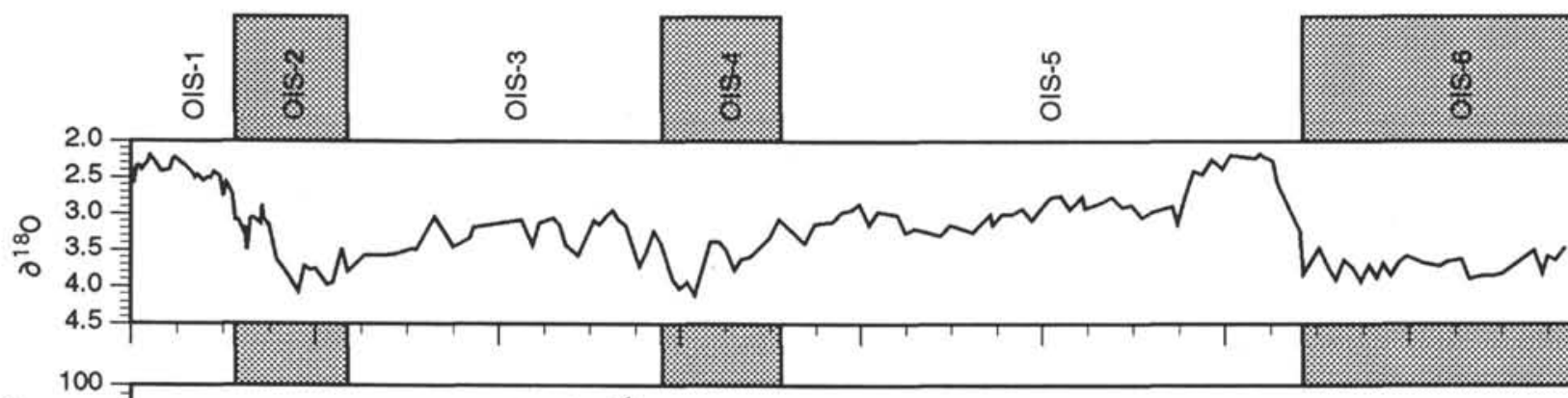

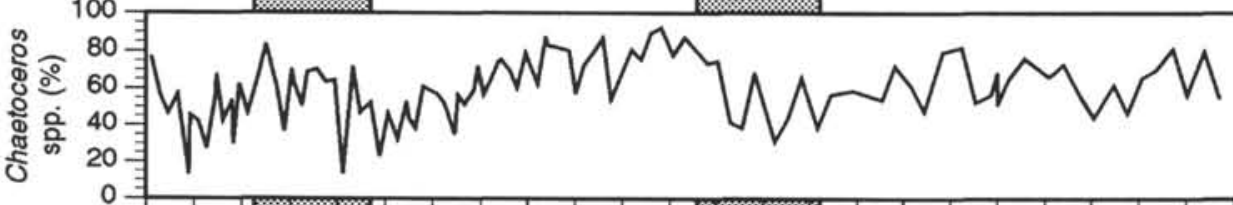

है

(1,

:

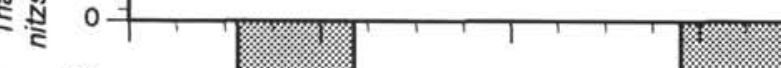

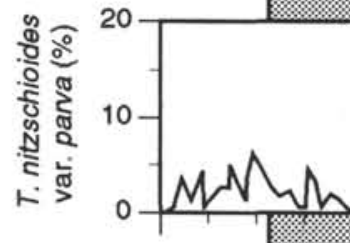

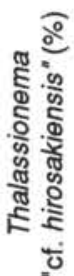

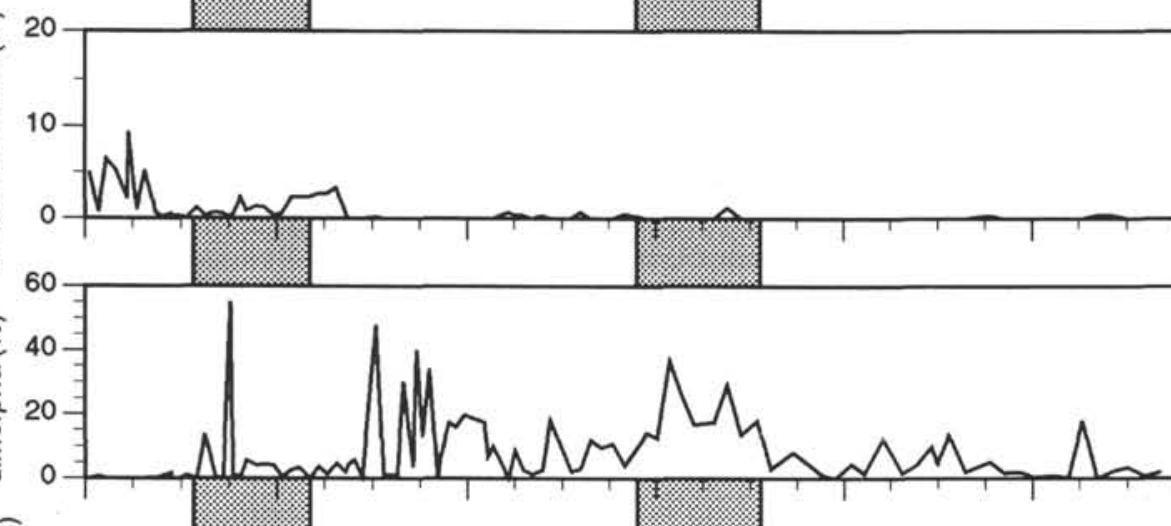

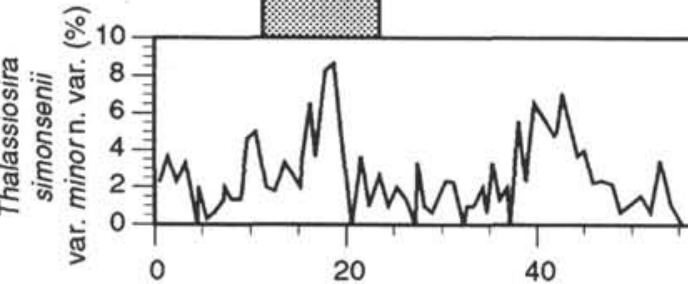
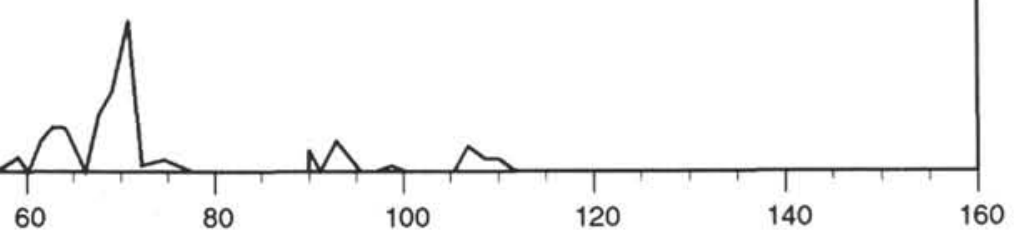

Age (ka)

Figure 2. Comparison of relative abundances of select diatom taxa with the oxygen-isotope curve of Kennett (this volume). 


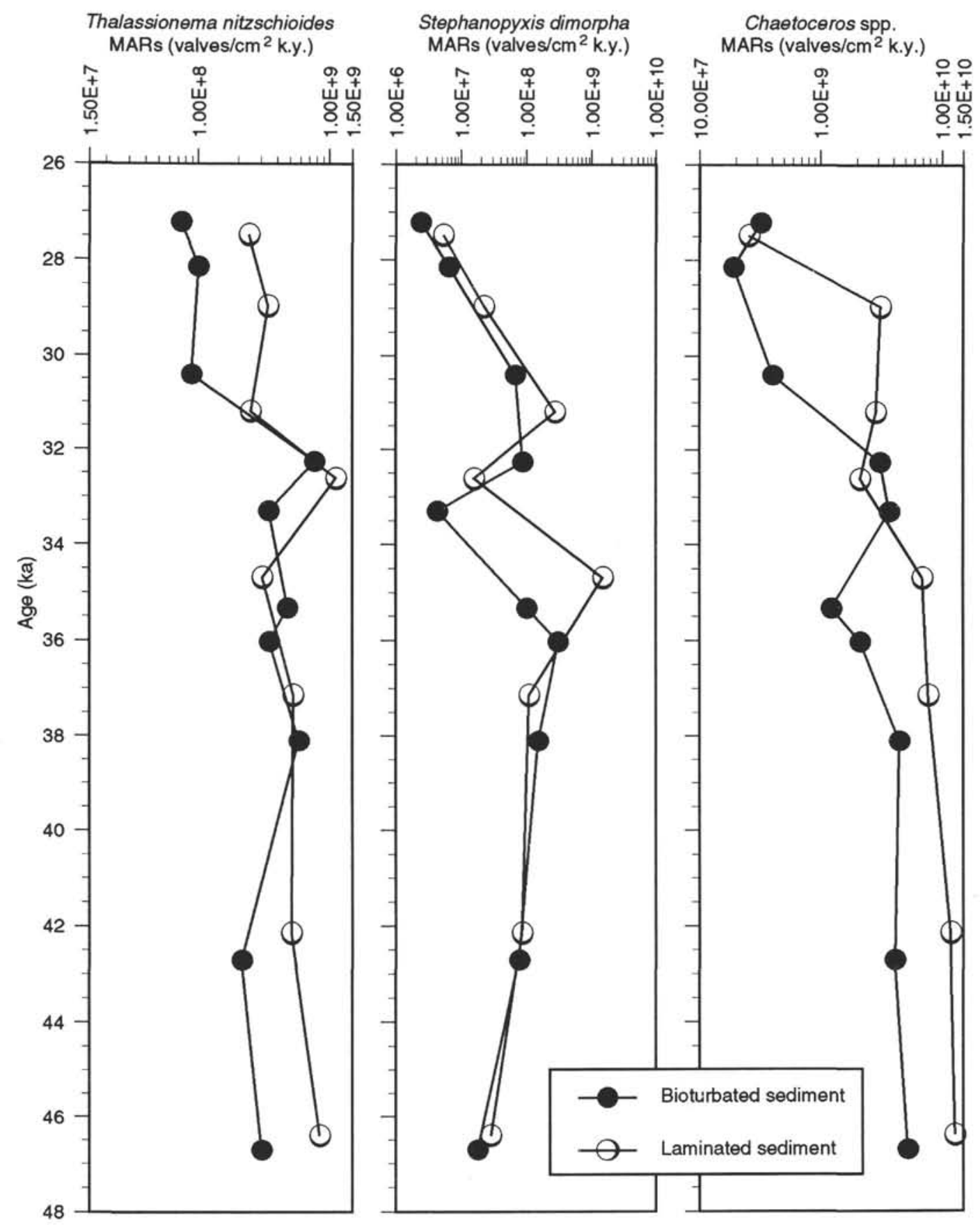

Figure 3. Differences in diatom concentrations for adjacent laminated and bioturbated intervals in Hole 893A, Cores 146-893A-6 H through 8H, as determined from diatom mass accumulation rates (MARs). Open circles = laminated intervals; closed circles = bioturbated intervals.

duces ambiguities that may arise from comparing samples from undisturbed laminated sediment, which represent a short time of accumulation, from samples from bioturbated sediment that may have been mixed over several centimeters. Fluctuating diatom productivity may be responsible in part for differences in diatom MARs between adjacent laminated and bioturbated intervals of OIS-3 age. but our observations suggest that preservation is the dominant factor. For example, offsets in MARs for Chaetoceros spp. in laminated as compared to bioturbated sediment are fairly consistent (Fig. 3), and qualitative examination indicates that many more delicate specimens are present in the laminated deposits than in the adjacent bioturbated deposits. In contrast, MARs for Stephanopyxis dimorpha, which has a dissolution-resistant frustule, show similar values for most adjacent laminated and bioturbated samples (Fig. 3), because specimens were not easily dissolved in bioturbated deposits. This suggests that an increase in $S$. dimorpha in a laminated sample at about 35 ka may represent an episode of increased flux of this species. MARs for Thalassionema nitzschioides are similar between some adjacent laminated and bioturbated intervals while others diverge, identifying this taxon's intermediate resistance to dissolution relative to delicate specimens of Chaetoceros and the sturdy valves of $S$. dimorpha.

Therefore, the diatom biostratigraphic record for Hole 893A is partly an artifact of preservation, and thus observations about diatom preservation represent an integral part of the analyses. For example, 


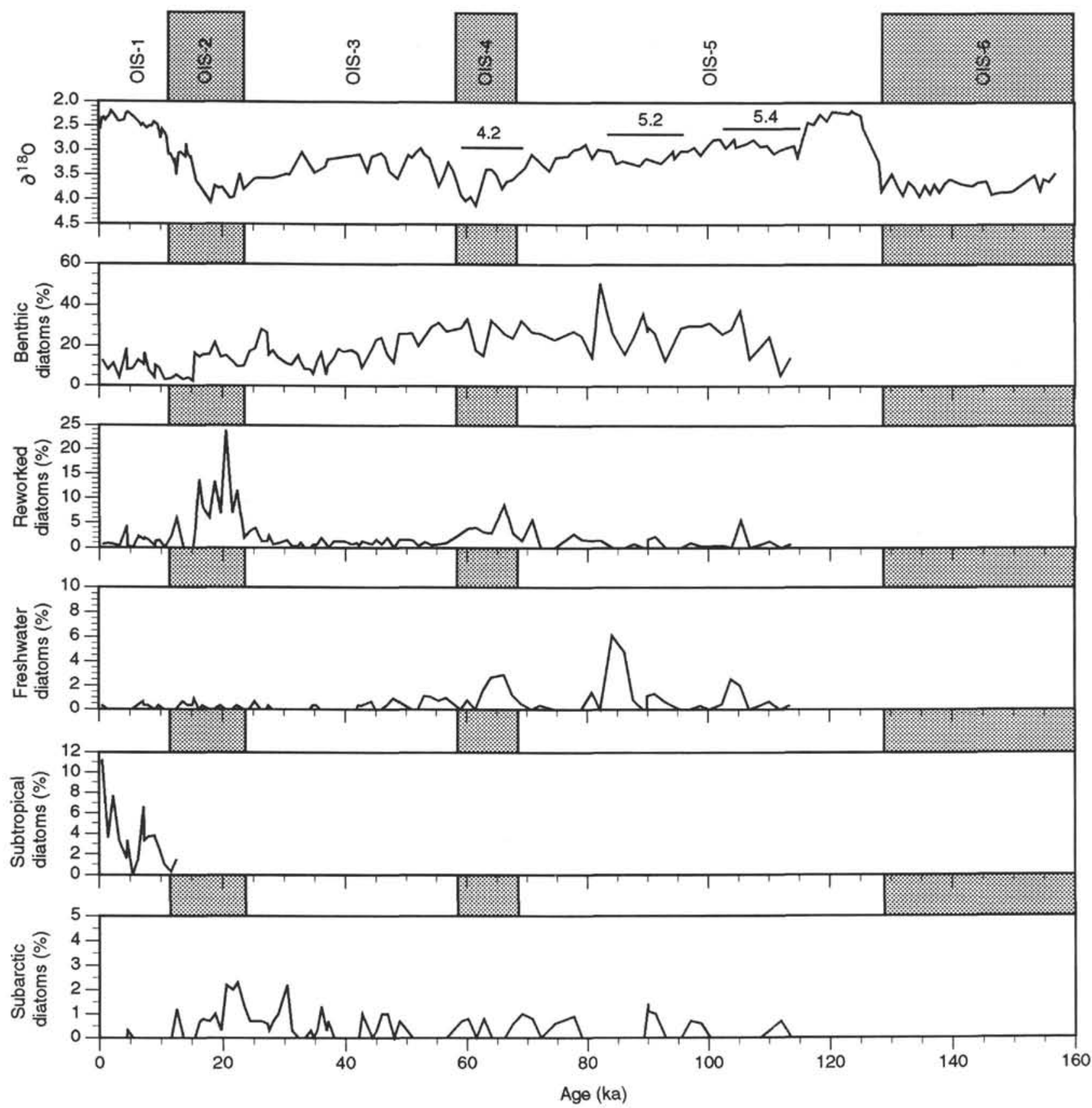

Figure 4. Comparison of relative abundances of subtropical, subarctic, benthic, reworked, and freshwater diatoms with the oxygen-isotope results of Kennett (this volume). Age ranges for cold peaks 4.2, 5.2, and 5.4 are from Martinson et al. (1987). Subtropical diatoms include Fragilariopsis doliolus, Azpeitia neocrenulatus, and Hemidiscus cuneiformis; subarctic species include Neodenticula seminae and Thalassiosira nidulus. Benthic diatoms include species associated with marine or brackish benthic environments (e.g., Cocconeis spp., Dimerogramma spp.); freshwater diatoms include species assumed to be allochthonous from freshwater environments (e.g., Eunotia spp., Pinnularia spp.).

downcore distributions of $S$. dimorpha (Fig. 2) in OIS-4 are probably at least partly the result of differential dissolution, whereas higher relative abundances of this species in well-preserved samples of OIS-3 may be paleoecologically significant. Downcore disappearances of delicate species like Skeletonema costatum (Fig. 2) can be attributed to dissolution (e.g., Reimers et al., 1990; Hemphill-Haley, 1993a), whereas downcore changes in sturdier species such as Cyclotella litoralis (Table 1, backpocket) cannot. Relative increases of sturdy benthic taxa in bioturbated sediment of OIS-4 and OIS-5 age (Fig. 4), as discussed below, may possibly reflect differential dissolution of less resistant marine planktonic species.

\section{PALEOCLIMATOLOGY}

Paleoclimatic events during the past 114,000 years in Santa Barbara Basin (OIS-1 to OIS-5d) are represented by differences in diatom preservation and abrupt shifts in diatom assemblages. Overall, 


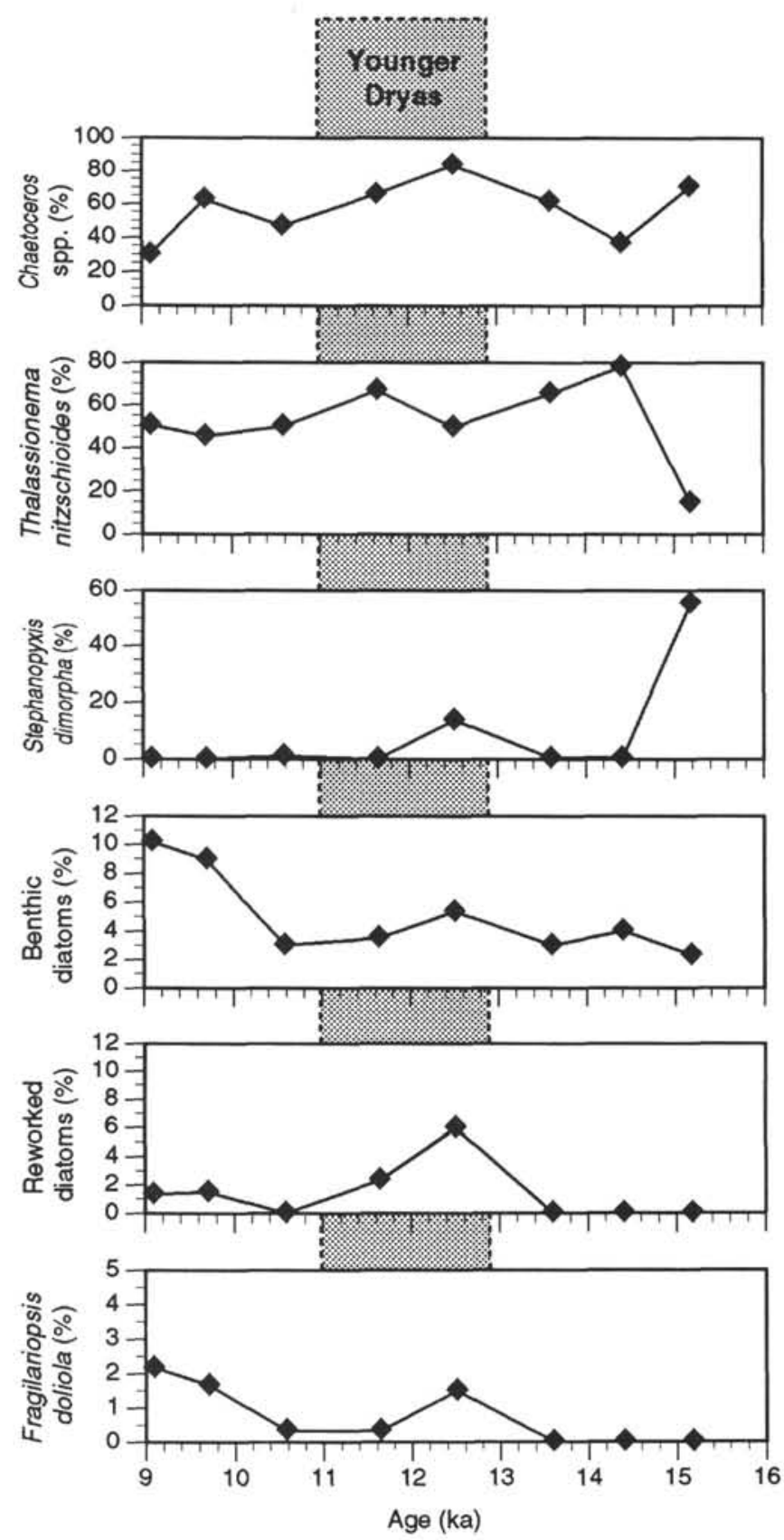

Figure 5. Relative abundances of diatom taxa during the Younger Dryas cooling event.

diatom assemblages are dominated by species that persist throughout the late Quaternary in the California Current (e.g., Thalassionema nitzschioides, Coscinodiscus radiatus, Thalassiosira eccentrica, and T. oestrupii; Schrader, 1973; Sancetta et al., 1992; Hemphill-Haley, 1993a), but in addition to these taxa are a number of less frequent species with more restricted stratigraphic ranges that are likewise significant for paleoclimatic and chronostratigraphic studies in the California Current.

\section{Oxygen Isotope Stage 1 and the 2/Stage 1 (Pleistocene/Holocene) Transition}

Oxygen isotope records indicate that the Pleistocene-Holocene transition was marked by an episode of rapid ice retreat and sea-level rise (Termination la) between 14.5-12 ka (Bard et al., 1987; Fairbanks, 1990). In the Coast Ranges of northern California, palynological evidence suggests a transition from a cool, moist Pleistocene climate to a Holocene climatic regime with cool winters and dry summers 14-12 ka (Adam, 1988; Rypins et al., 1989). Pollen studies in Santa Barbara Basin (Heusser, this volume) similarly suggest a shift to modern oak-dominated pollen assemblages about $14 \mathrm{ka}$.

An abrupt shift in diatom assemblages coeval to Termination Ia is recognizable in the California Current, and similarities between records off northern California (Hemphill-Haley and Gardner, 1994), Oregon (Sancetta et al., 1992), and Santa Barbara Basin (this paper) confirm a paleoclimatic connection between the southern and northern California Current. The transition from the Pleistocene to the Holocene is marked by the disappearance of several rare subarctic species (Neodenticula seminae and Thalassiosira nidulus) and the appearance of several subtropical species (Azpeitia neocrenulata, Hemidiscus cuneiformis, and especially Fragilariopsis (Pseudoeunotia) doliola) between about 14-12 ka (Fig. 4).

Modern floral studies indicate that $F$. doliola is associated with warmer sea-surface temperatures (SST) during the late fall and winter off California as coastal upwelling, which is responsible for bringing cold water to the surface, is diminished (Anderson et al., 1987; Reimers et al., 1990; Sautter and Sancetta, 1992). Sautter and Sancetta (1992) reported $F$. doliola as a dominant constituent of a winter pelagic assemblage in San Pedro Basin (Fig. 1), indicative of nonupwelling conditions and incursion of pelagic water from the subtropical gyre into the California Bight. The appearance of $F$. doliola during the late fall and winter is coincident with the maximum flow of the Southern California Counter Current and the Davidson Current, poleward-flowing surface currents that transport warm, saline waters northward along the California margin, and as far north as British Columbia (Halpern et al., 1978; Hickey, 1979, 1993). The appearance of subtropical diatoms during the Holocene, particularly $F$. doliola, therefore, may be the result of increased seasonal transport from the south via poleward-flowing currents. An increase in relative abundances of subtropical diatoms at about 9 ka (Fig. 2) is coeval with the Climatic Optimum, when summer radiation was $8 \%$ higher (COHMAP, 1988). Higher relative abundances of $F$. doliola and other subtropical species during the last few millennia may also suggest stronger seasonal poleward flow or higher winter SST in the California Current during the past $3 \mathrm{ka}$.

Oxygen isotope evidence from offshore northern California (Gardner et al., 1988) and in Santa Barbara Basin (Kennett, this volume) indicates that the two-step deglaciation observed in the North Atlantic, (Broecker et al., 1989; Fairbanks, 1989) is likewise observed in the California Current. However, there are no obvious changes in diatom assemblages in Hole $893 \mathrm{~A}$ coeval with Termination Ib.

\section{Younger Dryas Cooling Event}

Numerous studies from northern Europe and the North Atlantic support the theory that Terminations Ia and $\mathrm{Ib}$ were separated by a rapid return to glacial conditions about $11-10 \mathrm{ka}$, which is known as the Younger Dryas cooling event (Broecker et al., 1988; Kennett, 1990). On the Pacific Coast of North America, evidence for a possible Younger Dryas cooling has been recorded in maritime British Columbia (Mathewes et al., 1993), Washington (Heusser, 1977) and northern California (Gardner et al., 1988), but no evidence for such a cooling was observed off Oregon (Sancetta et al., 1992). The occurrence of a zone of bioturbated sediment from 17.73 to 20.42 mbsf within an otherwise continuous zone of laminated sediment provides a clue to the stratigraphic position of the Younger Dryas cooling in Santa Barbara Basin (Behl, this volume). Keigwin and Jones (1990) reported a similar change from laminated to bioturbated sediment coeval with the Younger Dryas cooling in the Gulf of California. Radiocarbon ages for the bioturbated interval in Hole 893A, $10.63 \mathrm{ka}$ to 


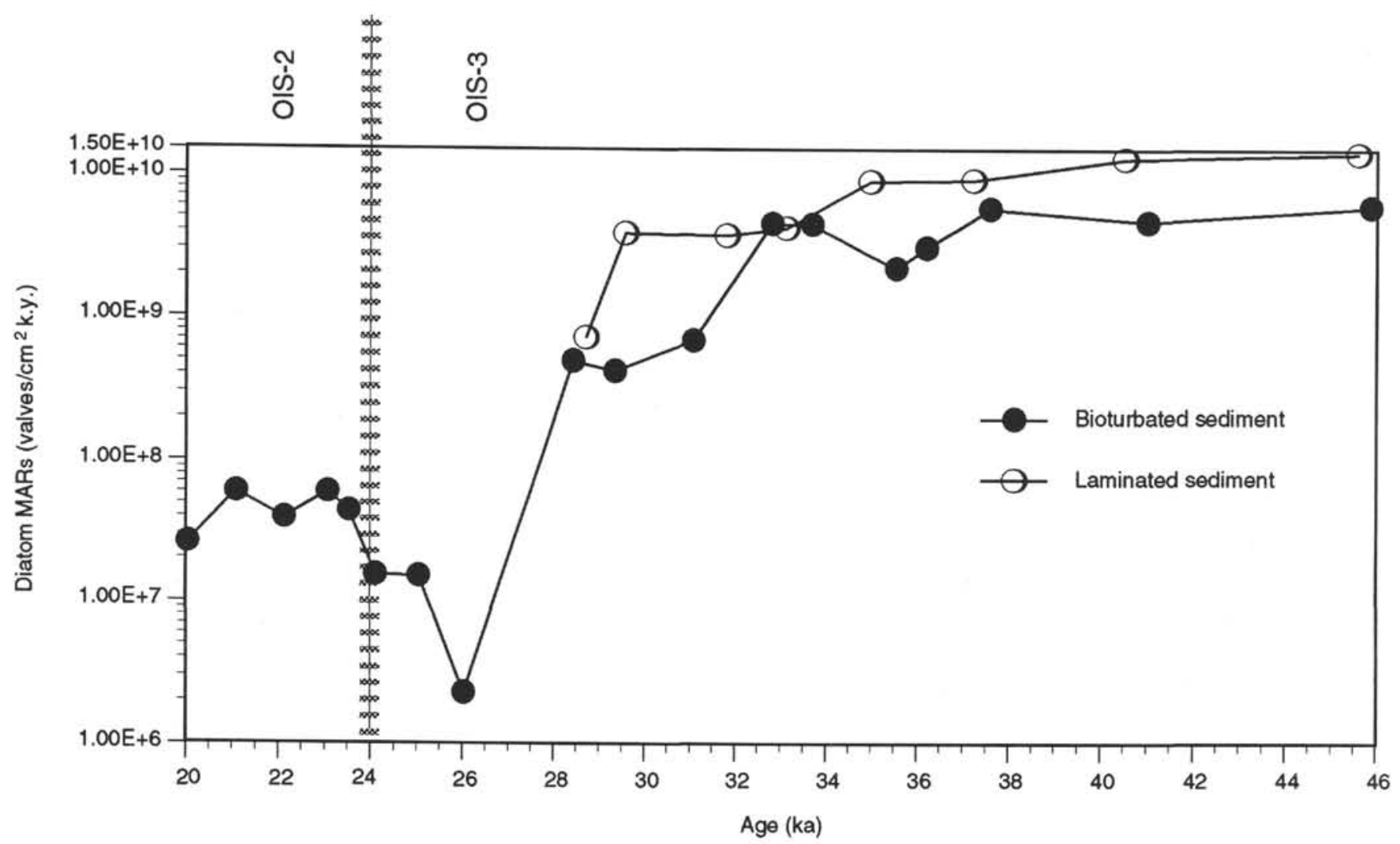

Figure 6. Differences in MARs for total diatoms for OIS-3 and OIS-2. Vertical line = OIS-3/OIS-2 boundary .

$11.98 \mathrm{ka}$ (or $11,060 \mathrm{cal}$ yr B.P. to $12,971 \mathrm{cal}$ yr B.P.; Behl, this volume), agree with ages for the Younger Dryas cooling reported elsewhere (Duplessy et al., 1989; Fairbanks, 1990), further suggesting that this cooling event was not restricted to the North Atlantic region as previously proposed (e.g., Broecker et al., 1988).

Diatom Samples 146-893A-3H-2, 110-111 cm, and 893A-3H-3, 95-96 cm, correspond to the Younger Dryas bioturbated interval in Hole 893A (Table 1, backpocket; Fig. 5). As in other bioturbated intervals, poor diatom preservation may have strongly affected the biostratigraphic signal. Most taxa show no obvious biostratigraphic changes associated with the Younger Dryas cooling (e.g., T. nitzschioides), and an increase in relative abundance of several taxa in the lower sample (e.g., Chaetoceros spp. resting spores, S. dimorpha, and reworked diatoms) is evidence for poor preservation in the bioturbated interval. Early incursions of subtropical species such as $F$. doliola $12-13 \mathrm{ka}$ in numerous cores off California and Oregon (Sancetta et al., 1992; Hemphill-Haley, 1993a; Hemphill-Haley and Gardner, 1994) may have been restricted by the onset of the Younger Dryas.

\section{Oxygen Isotope Stages 2 and 3}

In general, diatom assemblages in primarily bioturbated sediment of OIS-2 age are poorly preserved relative to assemblages from primarily laminated and intermittently laminated sediment of Holocene age at Site 893. Evidence for increased erosion and redeposition of fossil diatoms during lower eustatic sea level is suggested by higher relative abundances of reworked Miocene and Pliocene taxa during OIS-2 (Fig. 4). As discussed below, benthic diatoms persist throughout Hole 893 A, and do not increase in abundance relative to other diatoms during glacial intervals (Fig. 4). At $\sim 15 \mathrm{ka}$, an abrupt increase in Stephanopyxis dimorpha to $>50 \%$ occurs in an unusually well-pre- served sample (146-893A-3H-6, 70-71 cm) that contains abundant diatoms, including delicate taxa such as Skeletonema costatum (Fig. 2). The ecology of $S$. dimorpha is not well known (Schrader, 1973; C. Lange, pers. comm., 1994), but it is widely distributed in Quaternary deposits off California, and typically comprises $<5 \%$ of diatom assemblages in well-preserved samples (Hemphill-Haley, 1993a, and unpubl. data). Conversely, it may exceed $50 \%$ of diatom assemblages in poorly preserved samples after more delicate taxa are preferentially removed. Its unusual abundance at $\sim 15 \mathrm{ka}$ relative to a diverse, well-preserved assemblage, however, appears to represent a brief increase in productivity of this taxon.

Diatom MARs were calculated for samples between about $20 \mathrm{ka}$ and $46 \mathrm{ka}$ (Table 2) in order to examine changes in diatom concentration across the OIS-2/OIS-3 transition (Fig. 6). MARs for total diatoms (dominated by Chaetoceros spp.; Fig. 3) suggest that the high diatom fluxes of OIS- 3 were greatly diminished preceding the transition to glacial OIS-2. Alternating intervals of laminated and bioturbated sediment between 28-46 ka give way to consistently bioturbated sediment that persists from about 26 ka until the beginning of the Holocene (Behl, this volume). Differences in MARs for adjacent laminated and bioturbated samples between 28-46 ka are primarily due to poorer diatom preservation in bioturbated sediment, but MARs for both lithologies follow a similar trend suggesting (with an exception at $\sim 33 \mathrm{ka}$ ) an overall decrease in diatom flux from 46 to $28 \mathrm{ka}$. Between approximately 26 and $28 \mathrm{ka}$, laminated deposits cease and diatom MARs in bioturbated sediment plummet several orders of magnitude. Assuming that preservation is generally comparable between bioturbated sediment of OIS- 3 and OIS- 2 age, this suggests a large decrease in diatom flux preceding the transition to OIS-2. Diatom MARs increase somewhat with the onset of OIS-2 and remain relatively consistent until the glacial maximum at $20 \mathrm{ka}$, but at levels that are one to two orders of magnitude lower than comparable bio- 
Table 2. Mass accumulation rates (MARs, in valves $/ \mathrm{cm}^{2}$ k.y.) for total diatoms, Chaetoceros spp. resting spores, Stephanopyxis dimorpha, and Thalassionema spp. in Cores 146-893A-4H through $8 \mathrm{H}$.

\begin{tabular}{|c|c|c|c|c|c|c|c|c|}
\hline $\begin{array}{l}\text { Core, section, } \\
\text { interval }(\mathrm{cm})\end{array}$ & $\begin{array}{l}\text { Age } \\
\text { (ka) }\end{array}$ & $\begin{array}{l}\text { Depth } \\
\text { (mbsf) }\end{array}$ & $\begin{array}{l}\text { Sedimentary } \\
\text { structure }\end{array}$ & $\begin{array}{l}\text { Bulk } \\
\text { MARs }\end{array}$ & $\begin{array}{l}\text { Total diatoms } \\
\text { (MARs) }\end{array}$ & $\begin{array}{c}\text { Chaetoceros spp. } \\
\text { (MARs) }\end{array}$ & $\begin{array}{c}\text { Stephanopyxis } \\
\text { dimorpha (MARs) }\end{array}$ & $\begin{array}{c}\text { Thalassionema spp. } \\
\text { (MARs) }\end{array}$ \\
\hline \multicolumn{9}{|l|}{$146-893 \mathrm{~A}-$} \\
\hline $4 \mathrm{H}-5,2 \mathrm{l}-22$ & 20.06 & 31.41 & M & 70.5 & $1.81 \mathrm{E}+09$ & $1.50 \mathrm{E}+09$ & $4.95 E+06$ & $1.15 E+08$ \\
\hline $4 \mathrm{H}-6,31-32$ & 21.08 & 33.31 & M & 132.48 & $7.85 \mathrm{E}+09$ & $6.55 \mathrm{E}+09$ & $1.15 \mathrm{E}+07$ & $5.38 \mathrm{E}+08$ \\
\hline $4 \mathrm{H}-7,40-41$ & 22.13 & 34.9 & M & 132.48 & $5.12 \mathrm{E}+09$ & 4.26E+09 & $2.43 \mathrm{E}+07$ & $3.44 \mathrm{E}+08$ \\
\hline $5 \mathrm{H}-1,40-41$ & 23.07 & 35.4 & M & 132.48 & $7.86 \mathrm{E}+09$ & $6.49 \mathrm{E}+09$ & $4.12 \mathrm{E}+07$ & $7.11 \mathrm{E}+08$ \\
\hline $5 \mathrm{H}-1,119-120$ & 23.53 & 36.19 & M & 132.48 & $5.74 \mathrm{E}+09$ & $4.08 \mathrm{E}+09$ & $2.79 \mathrm{E}+07$ & $7.82 \mathrm{E}+08$ \\
\hline $5 \mathrm{H}-1,141-142$ & 23.66 & 36.41 & M & 132.48 & $7.41 E+09$ & $5.94 \mathrm{E}+09$ & $1.43 \mathrm{E}+07$ & $7.27 \mathrm{E}+08$ \\
\hline $5 \mathrm{H}-2,70-7 \mathrm{I}$ & 24.11 & 37.2 & M & 129.6 & $1.98 E+09$ & 1.13E+09 & $6.24 \mathrm{E}+06$ & $3.59 \mathrm{E}+08$ \\
\hline $5 \mathrm{H}-3,60-61$ & 25.05 & 38.6 & M & 129.6 & $1.93 \mathrm{E}+09$ & $1.32 \mathrm{E}+09$ & $5.43 E+06$ & $3.01 \mathrm{E}+08$ \\
\hline $5 \mathrm{H}-4,70-71$ & 26.03 & 40.2 & M & 132.48 & $2.99 \mathrm{E}+08$ & 1. $32 \mathrm{E}+08$ & $3.65 \mathrm{E}+06$ & $3.47 \mathrm{E}+07$ \\
\hline $5 \mathrm{H}-5,100-101$ & 28.42 & 41.39 & M & 130.64 & $4.84 E+08$ & $3.22 \mathrm{E}+08$ & $2.39 \mathrm{E}+06$ & $7.40 \mathrm{E}+07$ \\
\hline $5 \mathrm{H}-5,140-141$ & 28.71 & 41.79 & WL & 123.54 & 7.07E+08 & $2.56 \mathrm{E}+08$ & $5.32 \mathrm{E}+06$ & $2.41 \mathrm{E}+08$ \\
\hline $5 \mathrm{H}-6,110-111$ & 29.35 & 42.73 & M & 129.63 & 4.15E+08 & $1.92 \mathrm{E}+08$ & $6.52 \mathrm{E}+06$ & $1.01 \mathrm{E}+08$ \\
\hline $5 \mathrm{H}-7,20-21$ & 29.58 & 43.26 & WL & 129.63 & $3.82 \mathrm{E}+09$ & 3.14E+09 & $2.26 \mathrm{E}+07$ & $3.38 \mathrm{E}+08$ \\
\hline $6 \mathrm{H}-1,96-97$ & 31.09 & 45.27 & M & 129.63 & $6.77 \mathrm{E}+08$ & $4.05 \mathrm{E}+08$ & $6.75 \mathrm{E}+07$ & $8.84 \mathrm{E}+07$ \\
\hline $6 \mathrm{H}-2,90-91$ & 31.82 & 46.37 & WL & 154.96 & $4.48 \mathrm{E}+09$ & $3.12 \mathrm{E}+09$ & $8.78 E+07$ & $7.69 \mathrm{E}+08$ \\
\hline $6 \mathrm{H}-3,100-101$ & 32.81 & 47.85 & $\mathrm{M}$ & 154.96 & 3.69E+09 & $2.88 \mathrm{E}+09$ & $2.75 \mathrm{E}+08$ & $2.51 \mathrm{E}+08$ \\
\hline $6 \mathrm{H}-4,10-11$ & 33.13 & 48.34 & WL & 141.55 & 4.17E+09 & $2.13 E+09$ & $1.58 \mathrm{E}+07$ & $1.12 \mathrm{E}+09$ \\
\hline $6 \mathrm{H}-4,110-111$ & 33.69 & 49.29 & $\mathrm{M}$ & 141.55 & $4.43 \mathrm{E}+09$ & $3.71 \mathrm{E}+09$ & $4.31 \mathrm{E}+06$ & $3.43 \mathrm{E}+08$ \\
\hline $6 \mathrm{H}-6,10-11$ & 34.98 & 51.23 & WL & 132.61 & $8.91 \mathrm{E}+09$ & $6.91 \mathrm{E}+09$ & $1.47 \mathrm{E}+09$ & $3.06 \mathrm{E}+08$ \\
\hline $6 \mathrm{H}-6,110-111$ & 35.55 & 52.1 & $\mathrm{M}$ & 132.61 & $2.18 \mathrm{E}+09$ & 1.23E+09 & $1.01 \mathrm{E}+08$ & $4.77 \mathrm{E}+08$ \\
\hline $6 \mathrm{H}-7,60-6 \mathrm{I}$ & 36.21 & 53.08 & $\mathrm{M}$ & 132.61 & $3.06 \mathrm{E}+09$ & $2.14 \mathrm{E}+09$ & $3.05 \mathrm{E}+08$ & $3.45 \mathrm{E}+08$ \\
\hline $7 \mathrm{H}-2,100-101$ & 37.23 & 54.62 & $\mathrm{FL}$ & 132.61 & $9.11 E+09$ & $7.72 \mathrm{E}+09$ & $1.09 \mathrm{E}+08$ & $5.27 \mathrm{E}+08$ \\
\hline $7 \mathrm{H}-3,110-111$ & 37.60 & 55.97 & $\mathrm{M}$ & 132.61 & $5.73 E+09$ & $4.48 \mathrm{E}+09$ & $1.51 \mathrm{E}+08$ & $5.80 \mathrm{E}+08$ \\
\hline $7 \mathrm{H}-7,110-111$ & 40.53 & 61.59 & WL & 138.57 & $1.29 \mathrm{E}+10$ & $1.18 \mathrm{E}+10$ & $8.51 \mathrm{I}+07$ & $5.11 \mathrm{E}+08$ \\
\hline $7 \mathrm{H}-8,40-41$ & 41.11 & 62.36 & M & 143.04 & $4.65 \mathrm{E}+09$ & 4.12E+09 & $7.67 \mathrm{E}+07$ & $2.13 E+08$ \\
\hline $8 \mathrm{H}-5,28-29$ & 45.60 & 67.5 & WL & 143.04 & $1.41 \mathrm{E}+10$ & $1.28 \mathrm{E}+10$ & $2.88 \mathrm{E}+07$ & $8.41 \mathrm{E}+08$ \\
\hline $8 \mathrm{H}-5,70-71$ & 45.73 & 67.92 & M & 143.04 & $5.90 \mathrm{E}+09$ & $5.25 E+09$ & $1.80 \mathrm{E}+07$ & $3.02 \mathrm{E}+08$ \\
\hline
\end{tabular}

Notes: Sedimentary structure from Behl (this volume), as in Table 1. Bulk MARs from Gardner and Dartnell (this volume).

turbated deposits older than $28 \mathrm{ka}$. Therefore, in addition to the generally poorer diatom preservation in bioturbated sediment of OIS-2 age, there is also evidence for a decrease in diatom flux to Santa Barbara Basin relative to OIS-3.

These results suggest that diatom productivity, and by association, coastal upwelling, were reduced preceding the onset of glacial OIS-2 in Santa Barbara Basin. This agrees with previous studies in the California Current that have concluded that upwelling and productivity were diminished during OIS-2 relative to the Holocene (Sancetta et al., 1992; Lyle et al., 1992) or OIS-3 (Hemphill-Haley and Gardner, 1994).

During OIS-3, pulses of $S$. costatum between about 35-45 ka (Fig. 2) are approximately coeval with the accumulation of laminated deposits on the upper continental slope off California between $34^{\circ} \mathrm{N}$ and $39^{\circ} \mathrm{N}$ (Anderson et al., 1989; Gardner et al., 1992; Hemphill-Haley and Gardner, 1994). Evidence for high diatom flux in Santa Barbara Basin deposits (Fig. 6), including the anomalous occurrences of $S$. costatum, and the preservation of the laminated deposits on the continental slope to the north may indicate vigorous upwelling and high diatom flux along much of the California Current during this time.

\section{Oxygen Isotope Stages 4 and 5a-d}

Our interpretations for OIS- 4 and OIS- 5 are based on relative abundances of dominant taxa, as diatom MARs were not completed. OIS- 4 between about 60 and $70 \mathrm{ka}$ is characterized by relative increases in Stephanopyxis dimorpha (Fig. 2), benthic diatoms, and reworked diatoms (Fig. 4). There may be a strong preservational bias in some poorly preserved samples. Therefore, a general positive correlation between increased abundance of $S$. dimorpha and heavier isotopic values prior to about $35 \mathrm{ka}$ (Fig. 2) could indicate higher flux of this taxon to Santa Barbara Basin during cooler glacial periods, or preferential preservation of $S$. dimorpha relative to other taxa. A general negative correlation between relative abundances of Thalassionema nitzschioides and the oxygen isotope curve prior to about $55 \mathrm{ka}$ and during OIS-2 suggests that this species prefers overall warmer conditions off California during interglacials (Fig. 2), although its signal may also be biased by preservation.

During OIS-4 and OIS-5 prior to $60 \mathrm{ka}$, the relative abundance of Chaetoceros spp. is generally low (typically less than $60 \%$ of the assemblage), with the exception of fairly brief peaks of $80 \%$ between about 87 and 84 ka, 97 and 92 ka, and about 112 and 108 ka (Fig. 2). As previously stated, the relative abundance of Chaetoceros spp. correlates with the overall absolute flux of diatoms. Therefore, assuming similarities in preservation for OIS-3, OIS-4, and OIS- 5 bioturbated samples, it is possible that diatom productivity was lower during OIS- 4 and OIS-5 relative to the early part of OIS-3. Subtropical diatoms, including Fragilariopsis doliola, were not observed in OIS-5a to OIS-5d samples.

Benthic marine and estuarine diatoms, dominated by species of Cocconeis, persist throughout the Hole 893A record, and show no apparent correlation with the oxygen-isotope curve (Fig. 4). Similar observations of "abundant benthic diatoms and detritus" (Reimers et al., $1990)$ in surface samples from Santa Barbara Basin suggests that the influx of benthic material has persisted from OIS-5d to the present. A decrease in relative abundances of benthic diatoms since $15 \mathrm{ka}$ (Fig. 4) may reflect preferential preservation between the younger and older deposits (with fewer delicate marine taxa relative to sturdy benthic taxa preserved in older deposits), or an overall decrease in downslope transport as sea level rose after deglaciation.

Freshwater diatoms are rare throughout the Site 893 record (average less than $2 \%$; Fig. 4), but small increases in percentages of freshwater diatoms are observed within the range of the oxygen-isotope "events" (Martinson et al., 1987) OIS-4.2, OIS-5.2, and to a lesser extent OIS-5.4. Occasional fluvial pulses are probably not responsible for the incursion of freshwater taxa in Santa Barbara Basin, because freshwater diatoms are not associated with gray silt layers ("gray layers"; Table 1, backpocket) that are widely distributed in Santa Barbara Basin and the surrounding area (Thorton, 1986; Gardner et al., 1992) and that are known to originate predominantly from the Santa Clara River (Fleischer, 1972). Therefore, we propose that these small 
increases in freshwater taxa may be evidence for increased wind transport, in addition to downslope transport, of continental diatoms during cold intervals.

\section{SYSTEMATICS}

\section{Description of New Taxon and Transfer of Taxon}

Thalassiosira simonsenii var. minor Hemphill-Haley var. nov.

Description (after the description of $T$. simonsenii by Hasle and Fryxell, 1977, p. 23): Valva convexa, in ambitu circularis. Limbus valvae non altus, obliquus, in labrum horizontalem terminans. Diameter 14-30 $\mu \mathrm{m}$. Areolae loculatae, hexagonae, in seriebus linearibus. Foramina externa in ambitu circularia. Areola centralis quam ceteri parvior. Areolae in superficie valvae 6-7 in $10 \mu \mathrm{m}$, prope limbum et in limbo valvae parvior $(10$ in $10 \mu \mathrm{m}) ; 2$ 3 series verticales pororum inter costas marginales distinctas (10-12 costae in $10 \mu \mathrm{m})$. Rimoportulae duae radialiter positae, $180^{\circ}$ inter se semotae, in margine superficie valvae locatae, tubis longis externis. Fultoportula unica areolam centralem contigua. Annuli duo fultoportularum in margine valvae. Processus occlusi longi tubulares, in eodem annulo cum rimoportulis, numero atque distantia inter se (plerumque 1-2 in $10 \mu \mathrm{m}$ ) variabilis. Species marina planctonica.

(Valve convex, circular in outline. Valve mantle shallow, slanting, ending in a horizontal brim. Diameter 14-30 $\mu \mathrm{m}$. Hexagonal loculate areola in linear rows. External foramina circular in outline. Central areola smaller than others; 6-7 areolae in $10 \mu \mathrm{m}$ on valve face, smaller $(10$ in $10 \mu \mathrm{m}$ ) close to and in valve mantle; 2-3 vertical rows of pores between distinct marginal ribs (10-12 ribs in $10 \mu \mathrm{m}$ ). Two radially oriented labiate processes, $180^{\circ}$ apart, with long external tubes, located on edge of valve face. One strutted process adjacent to central areola. Two rings of strutted processes on valve mantle. Long tubular occluded processes in same ring as labiate processes, variable in number and distance between them ( $1-2$ in $10 \mu \mathrm{m}$ usually measured). Planktonic marine species.)

Remarks: This taxon differs from $T$. simonsenii var. simonsenii Hasle and Fryxell, 1977, by the smaller, convex valve (14-30 $\mu \mathrm{m}$ in diameter), and the greater number of areolae (6-7), marginal ribs (10-12), and marginal processes (1-2) in $10 \mu \mathrm{m}$. In comparison, $T$. simonsenii var. simonsenii, which was described from the tropical eastern Pacific, has a flattened valve that is slightly rounded at the margin, and 4-5 areolae, 8-10 marginal ribs, and about 1 marginal process in $10 \mu \mathrm{m}$. Occurrences of $T$. simonsenii var. simonsenii are very rare off California (Mahood et al., 1986; Hemphill-Haley, 1993a and unpubl. data), whereas $T$. simonsenii var. minor is consistently observed in late Quaternary deposits off California, particularly south of about $36^{\circ} \mathrm{N}$, to include Santa Barbara Basin (Fig. 2). It has also been consistently observed in recent surface-sediment and sediment-trap samples from Santa Barbara Basin, more often in winter laminae (C. Lange, pers. comm., 1994), as well as in the Gulf of California, and possibly the southwest Atlantic (C. Lange, pers. comm., 1994). These observations suggest that, in general, $T$. simonsenii var. minor is indicative of cooler sea-surface temperatures than the nominate variety.

Holotype: Plate 1, Figures 4-5 from Sample 893A-8H-5, 28-29 cm, Santa Barbara Basin, slide no. CAS \#217025 deposited in the Diatom Collection, California Academy of Sciences, San Francisco, $17 \mu \mathrm{m}$ diameter.

Paratype: Plate 1, Figure 6, same slide as the holotype, $20 \mu \mathrm{m}$ diameter.

Paralia sol (Kützing) Hemphill-Haley comb. nov.

Basionym: Melosira sol (Ehrenberg) Kützing, 1849, Spec. Alg. S. 31: Hustedt, 1927-66, I, p. 270, fig. 115; Sancetta, 1982, p. 231, pl. 3, fig. 4-5.

Remarks: Comparison of this taxon with the descriptions of Melosira and Paralia by Round et al. (1990) indicates that it properly belongs in the genus Paralia. Definitive valve characteristics include: (1) radial markings on the valve face, (2) a mantle that is sharply differentiated from the valve face, (3) well-developed ridges and grooves which serve to interlock valves, and (4) large pores at the edges of the valve face and mantle.

\section{Taxonomic References and Remarks}

Formal citation of the species used in the checklists is given in this section. A reference to at least a good figure is provided, and the reader is referred to these references for a more thorough taxonomic treatment.
Actinocyclus curvatulus Janisch in Schmidt, 1878: Schrader, 1973, pl. 19, fig. 2; Koizumi, 1973, pl. 1, fig. 1-6.

Actinocyclus octonarius Ehrenberg, 1838: as Actinocyclus ehrenbergii: Ralfs: Barron, 1980, pl. 1 fig. 5.

Actinoptychus senarius (Ehrenberg) Ehrenberg, 1838: Sancetta, 1982, p. 225 , pl. 1, fig. 7. (Pl. 2, Fig. 1).

Actinoptychus vulgaris Schumann, 1867: Sancetta, 1982, p. 225, pl. 1, fig. 8. (PI. 2, Fig. 2).

Arachnoidiscus ehrenbergii Bailey, 1849: Hustedt, 1927-66, I, p. 471, fig. 262.

Asterolampra marylandica Ehrenberg, 1844: Schrader, 1973, pl. 21, fig. 2.

Asteromphalus arachne (Brébisson) Ralfs in Pritchard, 1861: Barron, 1980, pl. 2 , fig. 2 .

Asteromphalus heptactis (Brébisson) Ralfs in Pritchard, 1861: Hustedt, $1927-$ 66, I, p. 494, fig. 277.

Azpeitia africana (Janisch) Fryxell and Watkins in Fryxell et al., 1986, figs. XXII, XXIII.

Azpeitia neocrenulata (Schmidt) Fryxell and Watkins in Fryxell et al., 1986, figs. XVI, XXVII-2A, B.

Azpeitia nodulifera (Schmidt) Fryxell and Sims in Fryxell et al., 1986, figs. XVII, XVIII-1 through 3.

Azpeitia tabularis (Grunow) Fryxell and Sims in Fryxell et al., 1986, fig. 14, 15, 30. (Pl. 2, Fig. 3).

Chaetoceros spp. valves and resting spores.

Remarks: Counts are based on the combined numbers of valves and resting spores for several species, including but not limited to:

Chaetoceros cinctus Gran, 1897: Cupp, 1943, p. 142, fig. 98. (PI. 5, Fig. 8 ).

Chaetoceros diadema (Ehrenberg) Gran, 1897: as C. subsecundus: Cupp, 1943, p. 130, fig. 83. (Pl. 5, Fig. 2)

Chaetoceros debilis Cleve, 1894: Cupp, 1943, p. 138, fig. 95. (PI. 5, Fig. 3)

Chaetoceros didymus Ehrenberg, 1846: Cupp, 1943, p. 121, fig. 75-A. (Pl. 5, Fig. 7?)

Chaetoceros radicans Schutt, 1895: Cupp, 1943, p. 141, fig. 97. (Pl. 5, Fig. 1)

Chaetoceros vanheurckii Gran, 1897: Cupp, 1943, p. 123, fig. 77. (PI. 5, Figs. 4,6$)$

Coscinodiscus marginatus Ehrenberg, 1843: Koizumi, 1973, p. 833, pl. 3, fig. 12-14; Schrader, 1973, pl. 20, fig. 7, 10.

Coscinodiscus oculus-iridis Ehrenberg, 1841: Sancetta, 1982, p. 229, pl. 2, fig. 2. (Pl. 2, Fig. 5)

Coscinodiscus radiatus Ehrenberg, 1841: Sancetta, 1987, p. 234, pl. 2, fig. 110.

Remarks: Smaller forms of $C$. radiatus were consistently observed in Santa Barbara Basin samples. These specimens are typically $15-30 \mu \mathrm{m}$ in diameter, with 3-4 areolae in $10 \mu \mathrm{m}$ near the center of the valve, 5-7 in $10 \mu \mathrm{m}$ near the margin. The areolae pattern is irregular to subradial. Sancetta (1987) noted that $C$. radiatus may range in size from 13 to $100 \mu \mathrm{m}$, and that the smaller specimens: (1) do not show an obvious radial areolae arrangement; and (2) usually have only one or two processes on the valve surface. Distributions and relative abundances of the small forms of $C$. radiatus follow closely those of large forms of $C$. radiatus in Santa Barbara Basin. (Pl. 2, Fig. 6-8).

Cyclotella litoralis Lange and Syvertsen, 1989: pls. 1-4. (PI. 2, Fig. 4)

Delphineis karstenii (Boden) Fryxell in Fryxell and Miller, 1978, p. 116, fig. 1-10.

Delphineis margaritalimbata Mertz, 1966, p. 27, pl. 6, fig. 1-3. (Pl. 2, Figs. 12-13)

Delphineis surirella (Ehrenberg) G.W. Andrews, 1981, p. 83, pl. 1-2, fig. 17.

Remarks: Distinguished by a very narrow sternum that broadens near the apices, with the longest striae near the middle of the valve composed of 5-6 areolae. (Pl. 2, Figs. 9-11)

Delphineis surirella var. australis (Petit) G.W. Andrews, 1981: Hustedt, 1927-66, II, p. 162, fig. 679d.

Remarks: Distinguished by the undulate sternum, with the longest striae near the middle of the valve composed 3-4 areolae. Not separated from the nominate variety in the analysis (Table 1, backpocket).(PI. 2, Figs. 10-11).

Endictya sp. 1: Hemphill-Haley, 1993b, p. 46, pl. 3, fig. 5,6. As Endictya oceanica Ehrenberg, 1845: Schrader, 1973, p. 705, pl. 20, fig. 11. 
Fragilariopsis doliola (Wallich) Medlin and Sims, 1993: as Pseudoeunotia doliolus: Schrader, 1973, p. 708, pl. 4, fig. 1-8. (Pl. 2, Fig. 16)

Hemidiscus cuneiformis Wallich, 1860: Fryxell et al., 1986, p. 25, fig. 26. (Pl. 2, Fig. 14).

Neodenticula seminae (Simonsen and Kanaya) Akiba and Yanagisawa, 1986: Akiba, 1986, pl. 25, figs. 28-32. (Pl. 2, Fig. 15).]

Nitzschia bicapitata Cleve 1900: Simonsen, 1974, pl. 35, fig. 3-15.

Nitzschia interruptestriata Simonsen, 1974, pl. 36, figs. 9-11; pl. 37; pl. 38, figs. 1-7. (Pl. 3, Figs. 1-2).

Nitzschia kolaczekii Grunow 1877: Akiba, 1986, pl. 24, fig. 5.

Nitzschia marina Grunow in Cleve and Grunow 1880: Schrader 1973, pl. 4, figs. 17-19.

Nitzschia sicula (Castracane) Hustedt, 1958: Hasle, 1960, p. 26, text fig. 16, pl. 7 , figs. 64,65 .

Odontella aurita (Lyngbye) Agardh, 1830: Sancetta, 1982, p. 234, pl. 3, fig. $11-12$.

Odontella longicruris Greville (1859): Cupp, 1943, fig. 111-A.

Paralia sulcata (Ehrenberg) Cleve, 1873: Hendey, 1964, p. 73, pl. 23, fig. 5.

Proboscia alata (Brightwell) Sundtrom, 1986: as Rhizosolenia alata: Schrader, 1973, pl. 10, fig. 12. (PI. 3, Fig. 6)

Psammodiscus nitidus (Gregory) Round and Mann, 1990: as Coscinodiscus nitidus: Hustedt, 1927-66, I, p. 414, fig. 221; Hendey, 1964, p. 76, pl. 23 fig. 12.

Pseudopodosira elegans (Sheshukova-Poretzkaya) Sheshukova-Poretzkaya, 1964: Sancetta, 1982, p. 236, pl. 4, fig. 1-2.

Rhaphoneis amphiceros (Ehrenberg) Ehrenberg, 1844: Hendey, 1964, p. 154. pl. 26, fig. $1-4$.

Rhizosolenia styliformis Brightwell, 1858: Schrader, 1973, p. 710, pl. 10, fig. $18-21$.

Roperia tesselata (Roper) Grunow in Van Heurck, 1883: Schrader, 1973, pl. 19, fig. 3-4, 8-9; Fryxell et al., 1986, p. 24.

Skeletonema costatum (Greville) Cleve, 1878: Hendey 1964, p. 91, pl. 7, fig. 3. (PI. 3, Fig. 3).

Stephanopyxis dimorpha Schrader, 1973, pl. 15, fig. 9-11. (PI. 3, Figs. 4-5, 9-10).

Stephanopyxis turris (Greville and Arnott) Ralfs, 1861: Schrader, 1973, p. 711, pl. 15, fig. 1-7; Sancetta, 1982, p. 238, pl. 4, fig. 9-10.

Thalassionema bacillaris (Heiden and Kolbe) Kolbe 1955: Simonsen 1974, pl. 24 , fig. 1 .

Thalassionema nitzschioides (Grunow) Van Heurck, 1896: Schrader, 1973, p. 712 , pl. 23, fig. 2,6, 8-10, 12-13, 26, 29, 34.

Remarks: $T$. nitzschioides sensu stricto usually has parallel margins, but may show a gentle inflation at the middle (Hallegraeff, 1986). A form with broader apices and a central inflation. "Thalassionema cf. hirosakiensis," was also recorded in Site 893 samples. Its valve is $24-54 \mu \mathrm{m}$ long. 3-6 $\mu \mathrm{m}$ wide, with broadly rounded to subrostrate apices. Marginal areolae are distinct, $8-10(12)$ in $10 \mu \mathrm{m}$. T. cf. hirosakiensis accounts for only a few percent of total diatom assemblages, particularly in sediment younger than $30,000 \mathrm{yr}$ in Santa Barbara Basin (Fig. 2). Transitional morphologies between $T$. cf. hirosakiensis and typical valves of $T$. nitzschioides are evident in Site 893 samples (compare Pl. 4, Figs. 6, 7, 9, 10, 12, 15 with Figs. 8, 11, 13, 14, 16-18), and may make the two forms difficult to separate. (Pl. 4, Figs. 2, 4-18).

Thalassionema nitzschioides var. parva Heiden and Kolbe, 1928: Koizumi and Tanimura, 1985, p. 291, pl. 6, fig. 11.

Remarks: Distinguished by the short valve (usually less than $10 \mu \mathrm{m}$ long) with parallel sides and bluntly rounded ends. Transitional forms between $T$. nitzschioides var. parva and smaller forms of $T$. nitzschioides (compare Pl. 4, Figs. 1, 3, 4 with Figs. 2, 5) are evident. (PI. 4, Figs. 1, 3 , and 4).

Thalassiosira decipiens (Grunow ex Van Heurck) Jörgensen, 1905: Hendey, 1964 , p. 87, pl. 1, fig. 5; Mahood et al., 1986, p. 138, fig. 62-67, 97-98.

Thalassiosira eccentrica (Ehrenberg) Cleve, 1904: Hasle, 1976, fig. 36; Mahood et al. 1986, p. 137, fig. 30-35, 102, (Pl. 3, Fig. 8).

Thalassiosira leptopus (Grunow) Hasle and Fryxell, 1977, fig. 1-14, 94-96. Thalassiosira lineata Jousé, 1968: Simonsen, 1974, pl. 1, figs. 4-7.

Thalassiosira nidulus (Tempére and Brun) Jousé, 196I: Akiba, 1986, p. 446, pl. 6, fig. 5-7.

Thalassiosira oestrupii (Ostenfeld) Proschkina-Lavrenko, 1956: Akiba, 1986, pl. 14, figs. 1-6. (Pl. 3, Fig. 7).

Thalassiosira pacifica Gran and Angst, 1931; Mahood et al., 1986, p. 138, fig. 49-55, 105 .

Thalassiosira simonsenii Hasle and Fryxell, 1977, figs. 26, 43, 97.

Thalassiosira trifulta Fryxell, 1979: Sancetta, 1982, p. 244, pl. 5, fig. 10-12.
Thalassiothrix longissima Cleve and Grunow, 1880: Schrader, 1973, pl. 23. fig. 7, 17-18; Koizumi, 1973, p. 834, pl. 8, fig. 16. (Pl. 4, Fig. 19).

Brackish and marine benthic and tychopelagic diatom species from the following genera were encountered in Site 893 samples:

Achnanthes, Amphora, Biddulphia, Caloneis, Catenula, Cocconeis, Cymatosira, Cymbella, Delphineis, Dimerogramma, Diploneis, Grammatophora, Mastogloia, Navicula, Nitzschia, Opephora, Plagiogramma, Pleurosigma, Rhaphoneis, Stauroneis, Synedra, Trachyneis, Trachysphenia. (PI. 5, Figs. 9-14).

Freshwater diatom species from the following genera were encountered in Site 893 samples:

Achnanthes, Aulacoseira, Eunotia, Fragilaria, Frustulia, Gomphonema, Hantzschia, Navicula. Nitzschia, Pinnularia, Rhopalodia, Stephanodiscus, Surirella, Synedra.

\section{Reworked diatoms encountered in Site 893 samples:}

Actinocyclus ingens Rattray, 1890

Denticulopsis dimorpha (Schrader) Simonsen emend. Akiba and Yanagisawa, 1986

Denticulopsis hustedtii (Simonsen and Kanaya) Simonsen, 1979

Denticulopsis hyalina (Schrader) Simonsen, 1979

Denticulopsis praedimorpha Barron ex Akiba, 1982a

Neodenticula kamtschatica (Zabelina) Akiba and Yanagisawa, 1986

Neodenticula koizumii Akiba and Yanagisawa, 1986 (Pl. 5, Fig. 16)

Nitzschia fossilis (Frenguelli) emend. Kanaya ex Schrader, 1973

Rhizosolenia barboi (Brun) Tempére and Peragallo, 1908 (Pl. 5, Fig. 15)

Rouxia californica Peragallo in Tempére and Peragallo, 1910

Synedra jouseana Sheshukova-Poretzkaya, 1962

Thalassionema hirosakiensis (Kanaya) Schrader, 1973

Thalassionema schraderi Akiba, 1982b

Thalassiosira antiqua (Grunow) Cleve in Cleve-Euler, 1951

\section{ACKNOWLEDGMENTS}

We thank Jack Baldauf (Ocean Drilling Program) for suggesting the project, and for advice along the way. We thank Albert Mahood (California Academy of Sciences, San Francisco) for his expertise with the SEM, and Roger Lewis (U.S.G.S., Menlo Park) for help in the lab and for preparing most of the photomicrographs. Critical reviews by John Barron and James V. Gardner (U.S.G.S., Menlo Park), Carina Lange (Scripps Institution of Oceanography), Constance Sancetta (Lamont Geological Observatory) steered our thinking and helped to improve the manuscript. This study was supported in part by the U.S. Geological Survey Correlation of the Marine and Terrestrial Records of Climate Project, which is part of the Global Change and Climate History Program.

\section{REFERENCES}

Adam, D.P., 1988. Pollen zonation and proposed informal climatic units for Clear Lake, California cores CL-73-4 and CL-73-7. In Sims, J.D. (Ed.), Late Quaternary Climate, Tectonism, and Lake Sedimentation in Clear Lake, Northern California Coast Ranges. Spec. Pap.-Geol. Soc. Am., 214:63-80.

Akiba, F., 1982a. Late Quaternary diatom biostratigraphy of the Bellingshausen Sea, Antarctic Ocean. Rep. Tech. Res. Cen. JNOC., 16:31-74.

Akiba, F., 1982b. Taxonomy and biostratigraphic significance of a new diatom, Thalassionema schraderi. Bacillaria, 5:43-61.

Akiba, F., 1986. Middle Miocene to Quaternary diatom biostratigraphy in the Nankai trough and Japan trench, and modified lower Miocene through Quaternary diatom zones for middle-to-high latitudes of the North Pacific. In Kagami, H., Karig, D.E., Coulbourn, W.T., et al., Init. Repts. DSDP, 87: Washington (U.S. Govt. Printing Office), 393-481.

Akiba, F., and Yanagisawa, Y., 1986. Taxonomy, morphology and phylogeny of the Neogene diatom zonal marker species in the middle-to-high latitudes of the North Pacific. In Kagami, H., Karig, D.E., Coulbourn, W.T., et al., Init. Repts. DSDP, 87: Washington (U.S. Govt. Printing Office), 483-554.

Anderson, R.Y., Gardner, J.V., and Hemphill-Haley, E., 1989. Variability of the late Pleistocene-early Holocene oxygen-minimum zone off northern 
California. In Peterson, D.H. (Ed.), Aspects of Climate Variability in the Pacific and Western Americas. Geophys. Monogr., Am. Geophys. Union, 55:75-84.

Anderson, R.Y.,Hemphill-Haley, E., and Gardner, J.V., 1987. Persistent late Pleistocene-Holocene seasonal upwelling and varves off the coast of California. Quat. Res., 28:307-313.

Andrews, G.W., 1981. Revision of the diatom genus Delphineis and morphology of Delphineis surirella (Ehrenberg) G.W. Andrews, n. comb. In Ross., R. (Ed.), Proceedings of the Sixth Symposium on Recent and Fossil Diatoms: Oslo (Koeltz Scientific Books), 81-92.

Bard, E., Arnold, M., Maurice, P., Duprat, J., Moyes, J., and Duplessy, J.-C., 1987. Retreat velocity of the North Atlantic polar front during the last deglaciation determined by ${ }^{14} \mathrm{C}$ accelerator mass spectrometry. Nature, 328:791-794.

Barron, J.A., 1980. Upper Pliocene and Quaternary diatom biostratigraphy of Deep Sea Drilling Project Leg 54, tropical eastern Pacific. In Rosendahl, B.R., Hekinian, R., et al., Init. Repts. DSDP, 54: Washington (U.S. Govt. Printing Office), 455-485.

Broecker, W.S., Andree, M., Wölfli, W., Oeschger, H., Bonani, G., Kennett, J.P., and Peteet, D.,1988. The chronology of the last deglaciation: implications to the cause of the Younger Dryas event. Paleoceanography, 3:119.

Broecker, W.S., Kennett, J.P., Flower, B.P., Teller, J.T., Trumbore, S., Bonani, G., and Wolfli, W., 1989. Routing of meltwater from the Laurentide ice sheet during the Younger Dryas cold episode. Nature, 341:318321.

Cleve-Euler, A., 1951-1955. Die Diatomeen von Schweden und Finnland, IV. Kongl. Svenska Vetenskaps Akad. Handl.. Ser. 4; 2(1):1-163 (1951); $3(3): 1-153$ (1952); 4(2):1-158 (1953); 4(5):1-255 (1953); 5(4):1-232 (1955).

COHMAP Members, 1988. Climatic changes of the last 18,000 years: observations and model simulations. Science, 241:1043-1052.

Cupp, E., 1943. Marine Plankton Diatoms of the West Coast of North America. Bull. Scripps Inst. Oceanogr., Tech. Ser. 5.

Duplessy, J.-C., Arnold, M., Bard, E., Juillet-Leclerc, A., Kallel, N., and Labeyrie, L., 1989. AMS ${ }^{14} \mathrm{C}$ study of transient events and of the ventilation rate of the Pacific Intermediate Water during the last deglaciation. Radiocarbon, 31:493-502.

Fairbanks, R.G., 1989. A 17,000-year glacio-eustatic sea level record: influence of glacial melting rates on the Younger Dryas event and deep-ocean circulation. Nature, 342:637-642.

Fairbanks, R.G., 1990. The age and origin of the "Younger Dryas Climate Event" in Greenland ice cores. Paleoceanography, 5:937-948.

Fleischer, P., 1972. Mineralogy and sedimentation history, Santa Barbara Basin, California. J. Sediment. Petrol., 42:49-58.

Fryxell, G.A., and Miller, W.I., III, 1978. Chain-forming diatoms: three araphid species. Bacillaria, 1:113-136.

Fryxell, G.A., Sims, P.A., and Watkins, T.P., 1986. Azpeitia (Bacillariophyceae): related genera and promorphology. Syst. Bot. Monogr., 13:174.

Gardner, J.V., Dean, W.E., and Kayen, R., 1992. USGS Cruise F2-92, central and southern California margin. Open-File Rep.-U.S. Geol. Surv., 92-342.

Gardner, J.V.. Heusser, L.E., Quinterno, P.J., Stone, S.M., Barron, J.A., and Poore, R.Z., 1988. Clear Lake record vs. the adjacent marine record: a correlation of their past 20,000 years of paleoclimatic and paleoceanographic responses. In Sims, J.D. (Ed.), Late Quaternary Climate, Tectonism, and Sedimentation in Clear Lake, Northern California Coast Ranges. Spec. Pap.-Geol. Soc. Am., 214:171-182.

Hallegraeff, G.M., 1986. Taxonomy and morphology of the marine planktonic diatoms Thalassionema and Thalassiothrix. Diatom Res., 1:57-80. [11-17-95]

Halpern, D., Smith, R.L., and Reed, R.K., 1978. On the California Undercurrent over the continental slope off Oregon. J. Geophys. Res., 83:13661372 .

Hasle, G.R., 1960. Phytoplankton and ciliate species from the tropical Pacific. Skr. Nor. Vidensk. -Akad. Kl.I: Mat.-Naturvedensk. Kl., 2:150.

Hasle, G.R., 1976. The biogeography of some marine planktonic diatoms. Deep-Sea Res., 23: 319-338.

Hasle, G.R., and Fryxell, G.A., 1977. The genus Thalassiosira: some species with a linear areola array. Nova. Hedwigia Beih., 54:15-66.

Hemphill-Haley, E., 1993a. Distribution and taxonomy of late Quaternary diatoms from gravity cores L13-81-G117, L13-81-G138, L13-81-G145, and TT197-G330, northern California continental slope. Open-File Rep.-U.S. Geol. Surv., 93-340.

Hemphill-Haley, E., 1993b. Taxonomy of recent and fossil (Holocene) diatoms (Bacillariophyta) from northern Willapa Bay, Washington. OpenFile Rep.-U.S. Geol. Surv., 93-289.

Hemphill-Haley, E., 1994. Diatom biostratigraphy and paleoproductivity in the California Current between $34^{\circ} \mathrm{N}$ and $40^{\circ} \mathrm{N}$ during the past 50,000 years. Geol. Soc. Am. Abstr. Progr., 26:254. (Abstract)

Hemphill-Haley, E., and Gardner, J.V., 1994. Revised ages for laminatedsediment intervals and a Holocene-marker diatom from the northern California continental slope. Quat. Res., 41:131-135.

Hendey, N.I., 1964. An Introductory Account of the Smaller Algae of British Coastal Waters. Fishery Investigations, Ser. 4, Pt. 5: Bacillariophyceae (Diatoms): Koenigstein (Koeltz Scientific Books).

Heusser, C.J., 1977. Quaternary palynology of the Pacific Slope of Washington. Quat. Res., 8:282-306.

Hickey, B.M., 1979. The California Current System-hypotheses and facts. Prog. Oceanogr., 8:191-279.

Hickey, B.M., 1993. Circulation over the Santa Monica-San Pedro Basin and Shelf. Prog. Oceanog., 30:37-115.

Hustedt, F., 1927-66. Die Kieselalgen Deutschlands, Österreichs und der Schweiz mit Berücksichtigung der übrigen Länder Europas sowie der angrenzenden Meeresgebiete, Pt. 1, 2, 3: Champaign, IL (Koeltz Sciemtific), Reprint 1991.

Keigwin, L.D., and Jones, G.A., 1990. Deglacial climatic oscillations in the Gulf of California. Paleoceanography, 5:1009-1023.

Kennett, J.P., 1990. The Younger Dryas cooling event: an introduction. Pale oceanography, 5:891-895.

Kennett, J.P., Baldauf, J.G., et al., 1994. Proc. ODP, Init. Repts., 146 (Pt. 2): College Station, TX (Ocean Drilling Program).

Koizumi, I., 1973. The late Cenozoic diatoms of Sites 183-193, Leg 19 Deep Sea Drilling Project. In Creager, J.S., Scholl, D.W., et al., Init. Repts. DSDP, 19: Washington (U.S. Govt. Printing Office), 805-855.

Koizumi, I.. and Tanimura, Y., 1985. Neogene diatom biostratigraphy of the middle latitude western North Pacific, Deep Sea Drilling Project Leg 86. In Heath, G.R., Burckle, L.H., et al., Init. Repts. DSDP, 86: Washington (U.S. Govt. Printing Office), 269-300. Lange, C.B., and Schimmelmann, A., 1994. Seasonal resolution of laminated sediments in Santa Barbara Basin: its significance in paleoclimatic studies. In Redmond, K.T., and Tharp, V.L. (Eds.), Proc. 1Oth Annu. Pac. Climate (PACLIM) Workshop. Tech. Rep.-Calif. Dep. Water Resour., 36.

Laws, R.A., 1983. Preparing strewn slides for quantitative microscopical analysis: a test using calibrated microspheres. Micropaleontology, 29:60-65.

Lyle, M., Zahn, R., Prahl, F., Dymond, J., Collier, R., Pisias, N., and Suess, E., 1992. Paleoproductivity and carbon burial across the California Current: the Multitracers Transect, $42^{\circ} \mathrm{N}$. Paleoceanography, 7:251-272.

Mahood, A.D., Fryxell, G.A., and McMillan, M., 1986. The diatom genus Thalassiosira: species from the San Francisco Bay system. Proc. Calif. Acad. Sci., 44:127-156.

Martinson, D.G., Pisias, N.G., Hays, J.D., Imbrie, J., Moore, T.C., Jr., and Shackleton, N.J., 1987. Age dating and the orbital theory of the ice ages: development of a high-resolution 0 to 300,000 -year chronostratigraphy. Quat. Res., 27:1-29.

Mathewes, R.W., Heusser, L.E., and Patterson, R.T., 1993. Evidence for a Younger Dryas-like cooling event on the British Columbia coast. Geology, 21:101-104.

Mertz, D., 1966. Mikropalaeontologische und sedimentologische Untersuchung der Pisco-Formation Suedperus. Palaeontographica B, 118:1-48.

Reimers, C.E., Lange, C.B., Tabak, M., and Bernhard, J.M., 1990. Seasona spillover and varve formation in the Santa Barbara Basin, California. Limnol. Oceanogr., 35:1577-1585.

Rines, J.E.B., and Hargraves, P.E., 1986. Considerations of the taxonomy and biogeography of Chaetoceros ceratosporus Ostf. and Chaetoceros rigidus Ostf. In Ricard, M. (Ed.), Proc. 8th Int. Diatom Symp., 1984: Koenigstein (Koeltz Scientific Books), 97-112.

Round, F.E., Crawford, R.M., and Mann, D.G., 1990. The Diatoms: Biology and Morphology of the Genera: Cambridge (Cambridge Univ. Press).

Rypins, S., Reneau, S.L., Byrne, R., and Montgomery, D.R., 1989. Palynologic and geomorphic evidence for environmental change during the Pleistocene-Holocene transition at Point Reyes Peninsula, central coastal California. Quat. Res., 32:72-87.

Sancetta, C., 1982. Distribution of diatom species in surface sediments of the Bering and Okhotsk Seas. Micropaleontology, 28:221-257. 
Sancetta, C., 1987. Three species of Coscinodiscus Ehrenberg from North Pacific sediments examined in the light and scanning electron microscopes. Micropaleontology, 33:230-241.

Sancetta, C., and Calvert, S.E., 1988. The annual cycle of sedimentation in Saanich Inlet, British Columbia: implications for the interpretation of fossil assemblages. Deep-Sea Res., 35:71-90.

Sancetta, C.. Lyell, M., Heusser, L., Zahn, R., and Bradbury, J.P., 1992. Late-glacial to Holocene changes in winds, upwelling, and seasonal production of the Northern California current system. Quat. Res., 38:359370 .

Sautter, L.R., and Sancetta, C., 1992. Seasonal associations of phytoplankton and planktic foraminifera in an upwelling region and their contribution to the seafloor. Mar. Micropaleontol., 18:263-278.

Schimmelmann, A., Lange, C.B., and Berger, W.H., 1990. Climatically controlled marker layers in Santa Barbara basin sediments, and fine-scale core-to-core correlation. Limnol. Oceanogr., 35:165-173.

Schrader, H.-J., 1973. Cenozoic diatoms from the Northeast Pacific, Leg 18. In Kulm, L.D., von Huene, R., et al., Init. Repts. DSDP. 18: Washington (U.S. Govt. Printing Office), 673-797.
Simonsen, R., 1974. The diatom plankton of the Indian Ocean expedition of R/V Meteor, 1964-1965. In "Meteor" Forschunsergeb., Reihe D (No. 19): Biologie: Berlin-Stuttgart (Gebrüder Borntraeger).

Soutar, A., and Crill, P.A., 1977. Sedimentation and climatic patterns in the Santa Barbara Basin during the 19th and 20th centuries. Geol. Soc. Am. Bull., 88:1161-1172.

Tempére, J., and Peragallo, M., 1910. Diatomées du Monde Entier (2nd ed.): Arcachon (Grezsur-Loing), 209-256.

Thorton, S.E., 1986. Origin of mass flow sedimentary structures in hemipelagic basin deposits: Santa Barbara Basin, California Borderland. GeoMar. Lett., 6:15-19.

Date of initial receipt: 6 September 1994

Date of acceptance: 3 January 1995

Ms 146SR-280 

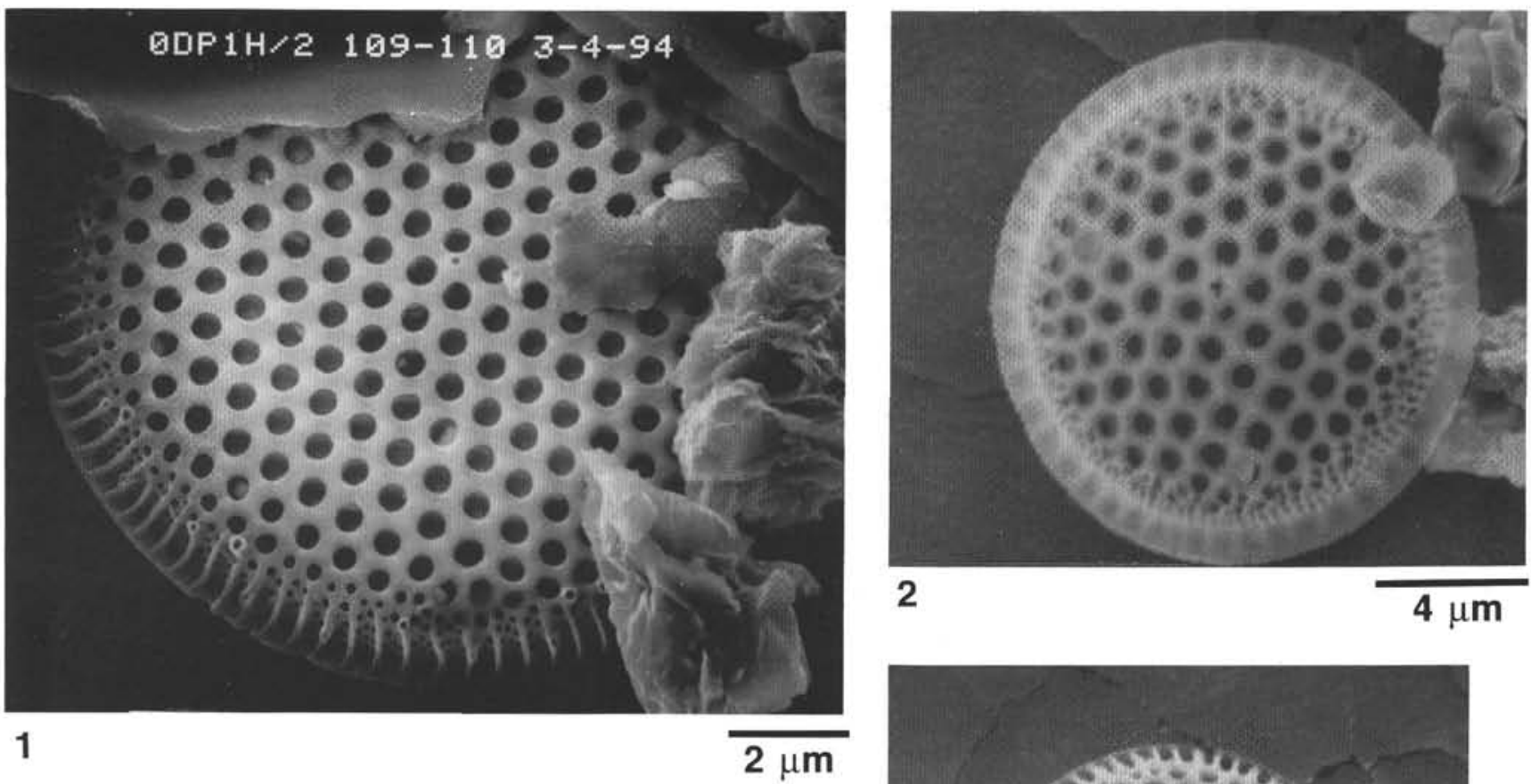

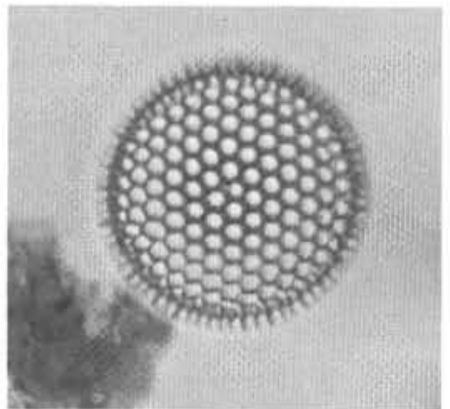

4

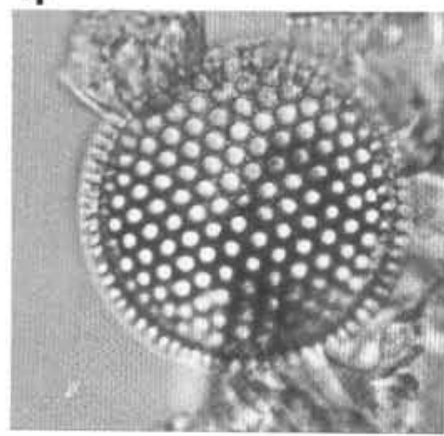

6

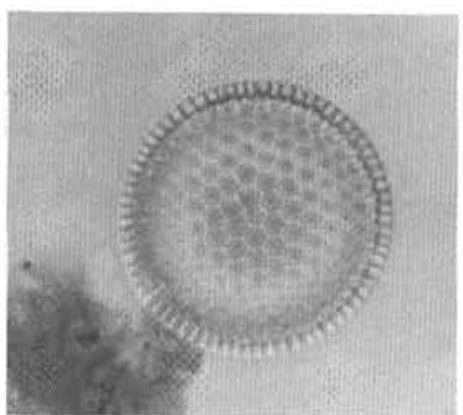

5

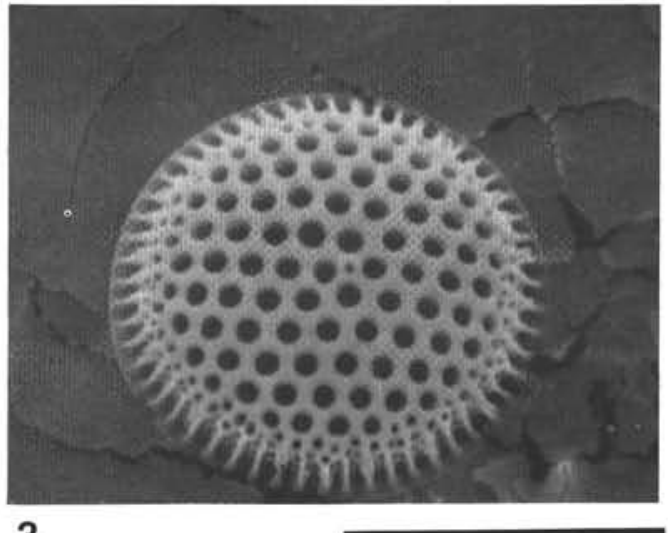

$10 \mu \mathrm{m}$

3

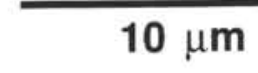

Plate 1. 1-6. Thalassiosira simonsenii var. minor Hemphill-Haley n. var., (1) Sample 146-893A-1H-2, 109-110 cm, SEM scale bar = $2 \mu \mathrm{m}$, (2) Sample 146-893A-1H-2, 109-110 cm, SEM scale bar $=4 \mu \mathrm{m}$, (3) Sample 146-893A-1H-2, 109-110 cm, SEM scale bar $=10 \mu \mathrm{m},(4,5)$ holotype, Sample 146893A-8H-5, 28-29 cm. (4) focus on center, (5) focus on margin, (6) Sample 146-893A-8H-5, 28-29 cm, focus on margin. (Magnification for Figs. 4-6: $\times 1500$ ). 

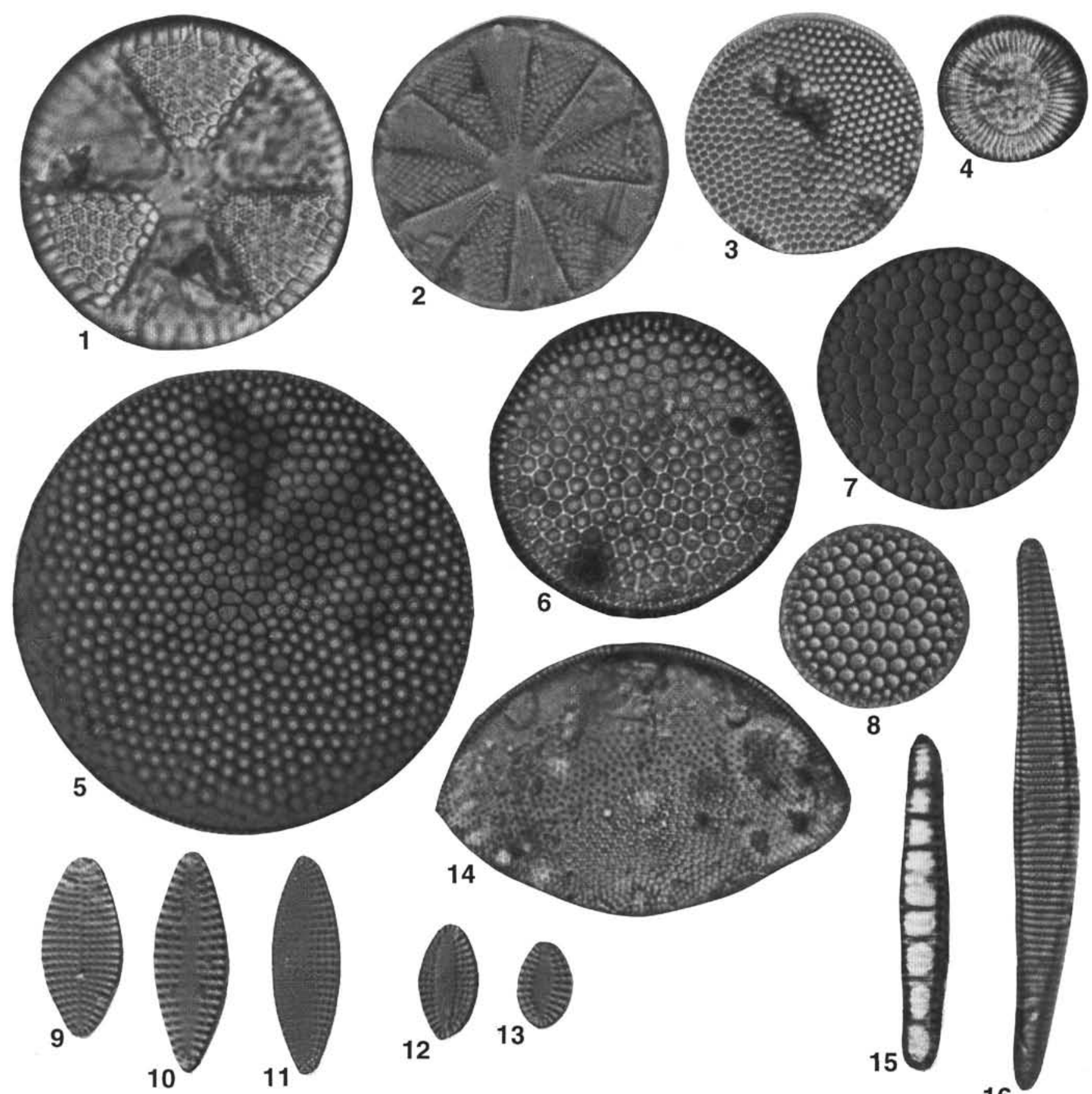

8
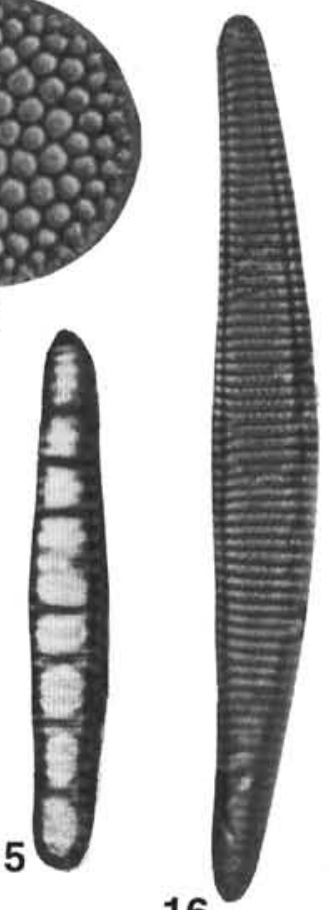

16

Plate 2. 1. Actinoptychus senarius (Ehrenberg) Ehrenberg, Sample 146-893A-8H-5, 28-29 cm. 2. Actinoptychus vulgaris Schumann, Sample 146-893A-8H5, 28-29 cm. 3. Azpeitia tabularis (Grunow) Fryxell \& Sims, Sample 146-893A-8H-5, 28-29 cm. 4. Cyclotella litoralis Lange and Syvertsen, Sample 146893A-8H-5, 28-29 cm. 5. Coscinodiscus oculus-iridis Ehrenberg, Sample 146-893A-14H-4, 90-91 cm. 6-8. Coscinodiscus radiatus Ehrenberg, (6) Sample 146-893A-1 H-1, 100-101 cm, large form with distinguishable radial areolae pattern, (7) Sample 146-893A-1H-1, 100-101 cm, small form with sub-radial areolae pattern, (8) Sample 146-893A-9H-7, 90-91 cm, small form with irregular areolae pattern. 9. Delphineis surirella (Ehrenberg) G.W. Andrews, (9) Sample 146-893A-11H-6, 104-105 cm. 10, 11. Delphineis surirella var. australis (Petit) G.W. Andrews, (10) Sample 146-893A-11 H-6, 104-105 cm, (11) Sample 146-893A-13H-5, 100-101 cm. 12, 13. Rhaphoneis margaritalimbata Mertz, Sample 146-893A-11H-6, 104-105 cm. 14. Hemidiscus cuneiformis Wallich, Sample 146-893A-8H-5, 28-29 cm. 15. Neodenticula seminae (Simonsen \& Kanaya) Akiba \& Yanagisawa, Sample 146-893A-8H-5, 28-29 cm. 16. Fragilariopsis doliolus (Wallich) Medlin \& Sims, Sample 146-893A-1H-1, 28-29 cm. (Magnification $\times 1500$ ). 


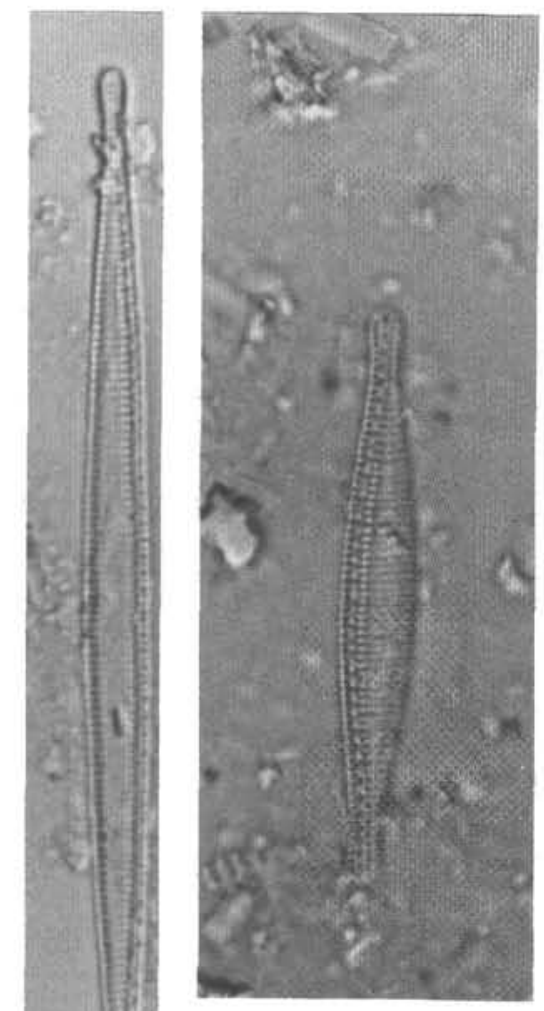

2

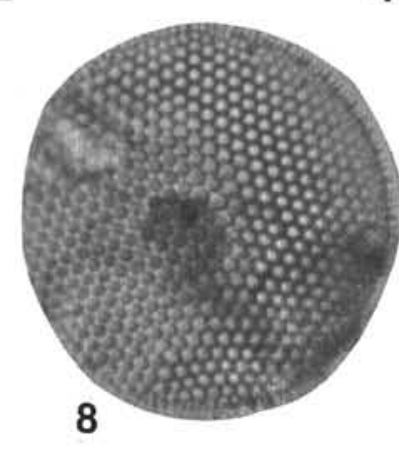

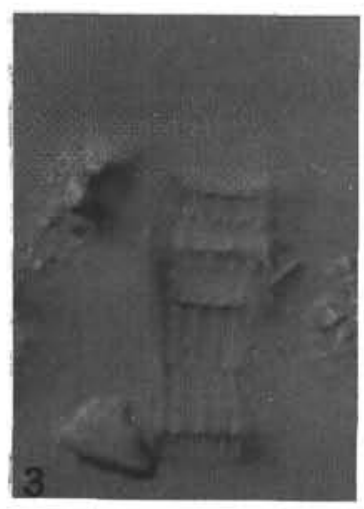

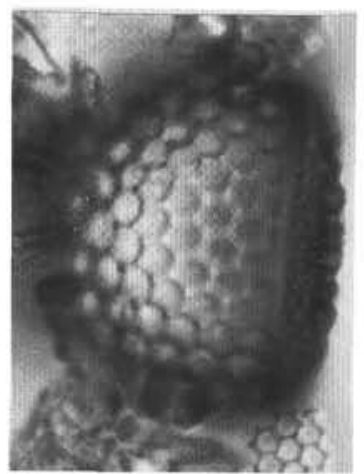

4

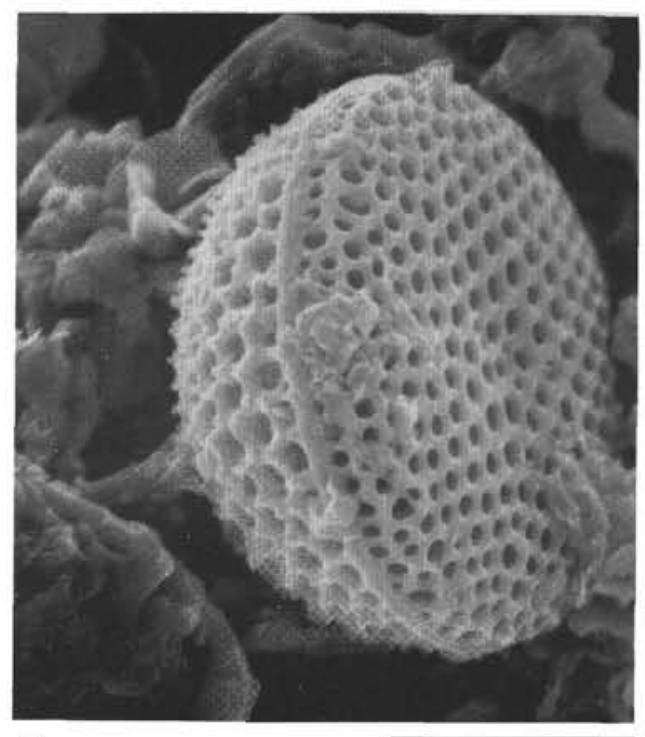

5

$10 \mu \mathrm{m}$

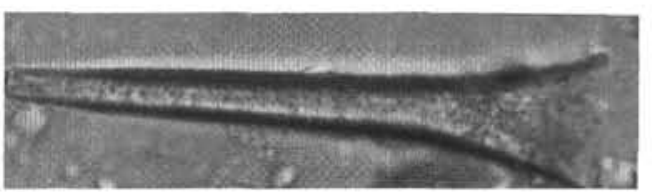

6

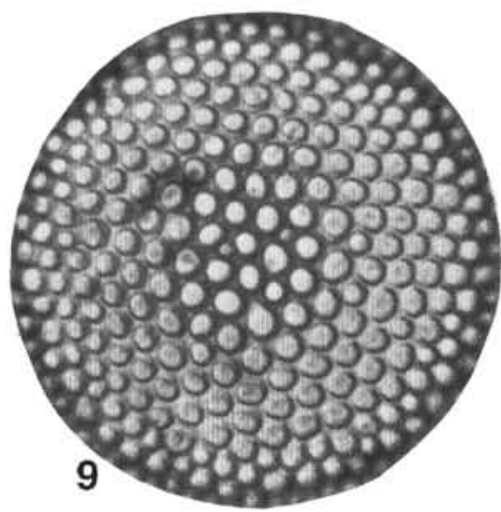

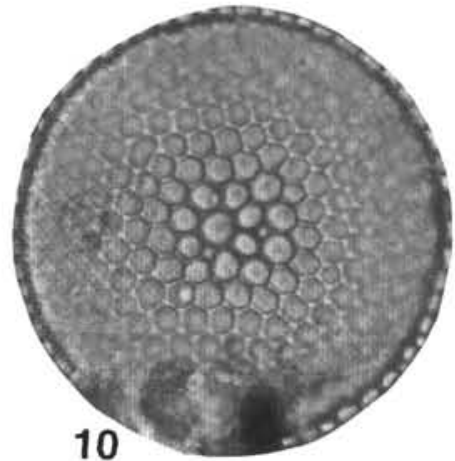

Plate 3. 1, 2. Nitzschia interruptestriata Simonsen, Sample 146-893A-1H-4, 109-110 cm. 3. Skeletonema costatum (Greville) Cleve, Sample 146893A-9H-1, 100-101 cm. 4, 5. Stephanopyxis dimorpha Schrader, (4) Sample 146-893A-8H-5, 28-29 cm, (5) SEM scale bar $=10 \mu \mathrm{m}$, Sample 146893A-6H-6, 10-11 cm. 6. Proboscia alata (Brightwell) Sundström, Sample 146-893A-1H-4, 109-110 cm. 7. Thalassiosira oestrupii (Ostenfeld) Proschkina-Lavrenko, Sample 146-893A-1H-4, 109-110 cm. 8. Thalassiosira eccentrica (Ehrenberg) Cleve, Sample 146-893A-8H-5, 28-29 cm. 9, 10. Stephanopyxis dimorpha Schrader, Sample 146-893A-8H-5, 28-29 cm, (9) focus on central processes, (10) focus on margin. (Magnification $\times 1500$ ). 

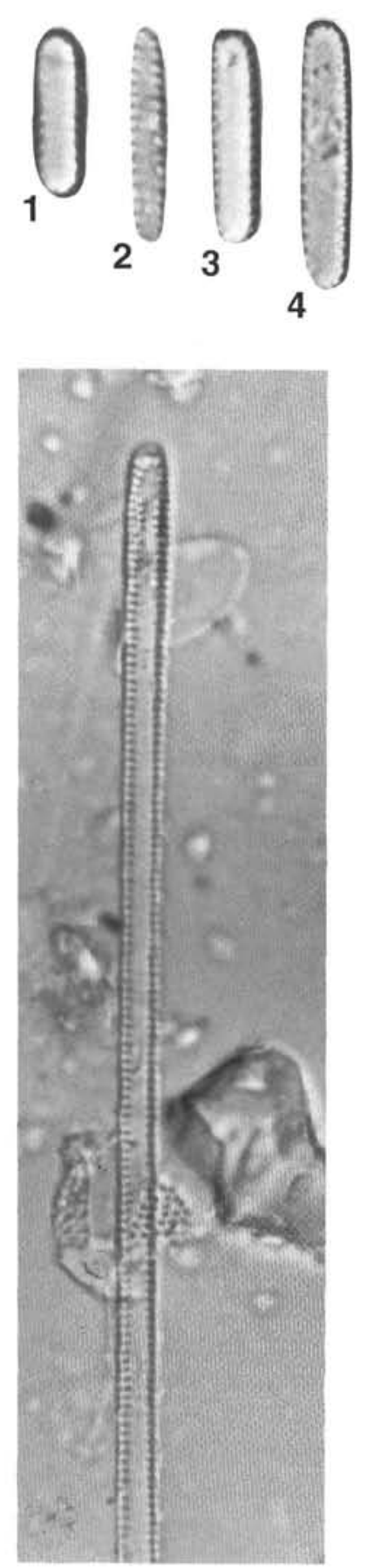
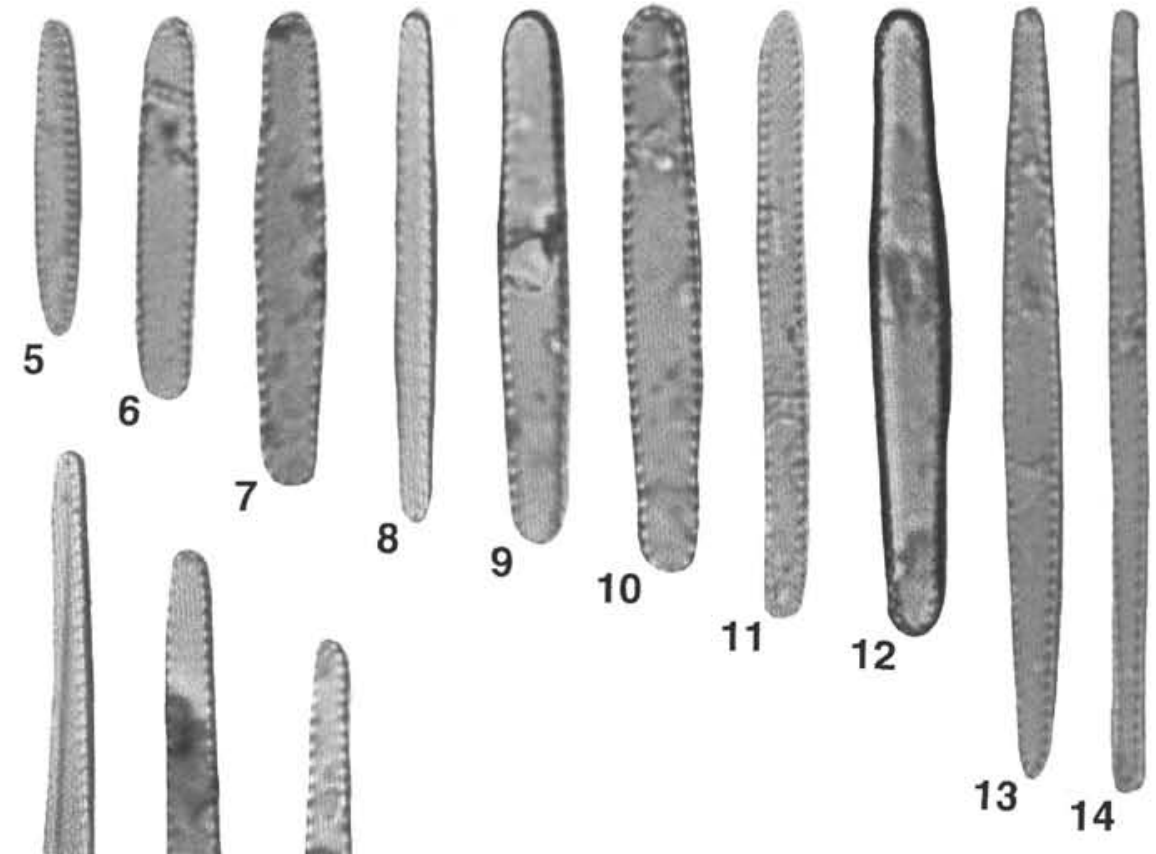
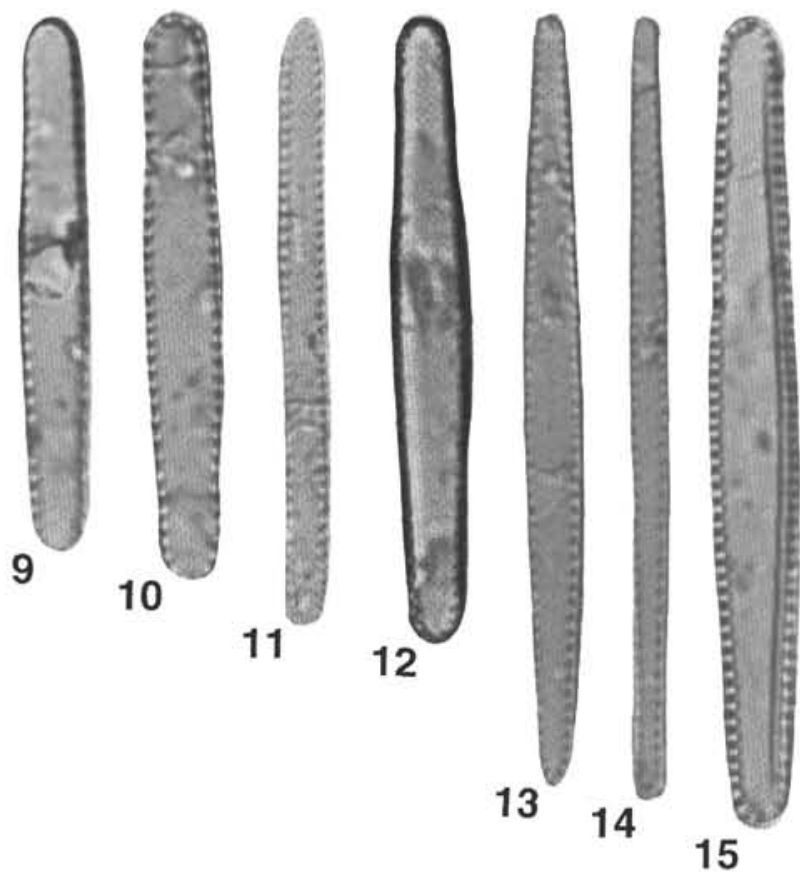

\section{9}

Plate 4. 1, 3, 4. Thalassionema nitzschioides var, parva Heiden \& Kolbe, (1) Sample 146-893A-1H-4, 109-110 cm; (3, 4) Sample 146-893A-8H-5, 28-29 cm. 2, 5-18. Thalassionema nitzschioides (Grunow) Van Heurck, $(6,7,9,10,12,15)$ robust forms of $T$. nitzschioides ("Thalassionema cf. hirosakiensis"), $(2,5,8,17)$ Sample 146-893A-8H-5, 28-29 cm, (9-11, 13-16, 18) Sample 146-893A-1H-4, 109-110 cm, (6, 7, 12) Sample 146-893A-1H-1, 100-101 cm. 19. Thalassiothrix longissima Cleve \& Grunow, Sample 146-893A-1H-4, 109-110 cm. (Magnification $\times 1500)$. 

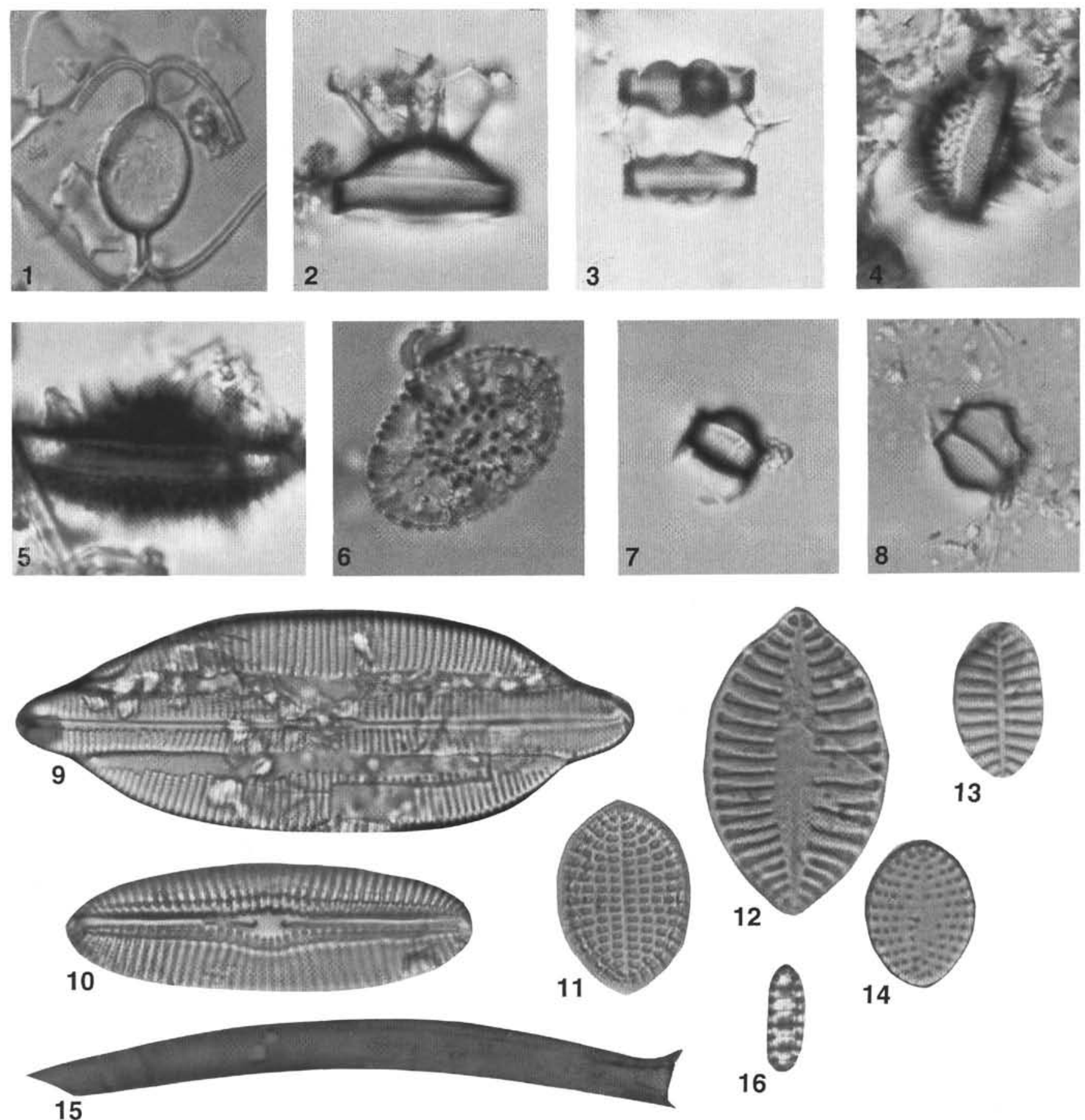

Plate 5. 1-8. Chaetoceros spp., (1-3, 5-6, 8) Sample 146-893A-8H-5, 28-29 cm, (4, 7) Sample 146-893A-1H-4, 109-110 cm, (1) Chaetoceros radicans Schutt resting spore, (2) Chaetoceros diadema (Ehrenberg) Gran resting spore, (3) Chaetoceros debilis Cleve paired resting spores, $(4,5$ ?, 6) Chaetoceros vanheurckii Gran. resting spores, (7) Chaetoceros didymus Ehrenberg? resting spore, (8) Chaetoceros cinctus Schutt paired resting spores. 9-14. Benthic diatoms, (9-11) Sample 146-893A-8H-5, 28-29 cm, (12) Sample 146-893A-1H-4, 109-110 cm, (13) Sample 146-893A-1H-1, 100-101 cm, (9) Navicula sp., (10) Diploneis sp., (11-13) Cocconeis spp., (14) Rhaphoneis psammicola Rizynk. 15, 16. Reworked diatoms, (15) Rhizosolenia barboi (Brun) Tempére and Peragallo, Sample 146-893A-8H-7, 90-91 cm, (16) Neodenticula koizumii Akiba and Yanagisawa, Sample 146-893A-1H-4, 109-110 cm. (Magnification $\times 1500$ ). 